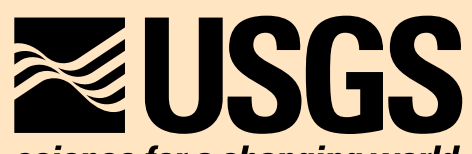

science for a changing world

Studies by the U.S. Geological Survey in Alaska, 2007

\title{
The Longview/Lakeview Barite Deposits, Southern National Petroleum Reserve, Alaska (NPRA)—Potential-field Models and Preliminary Size Estimates
}

Professional Paper 1760-C

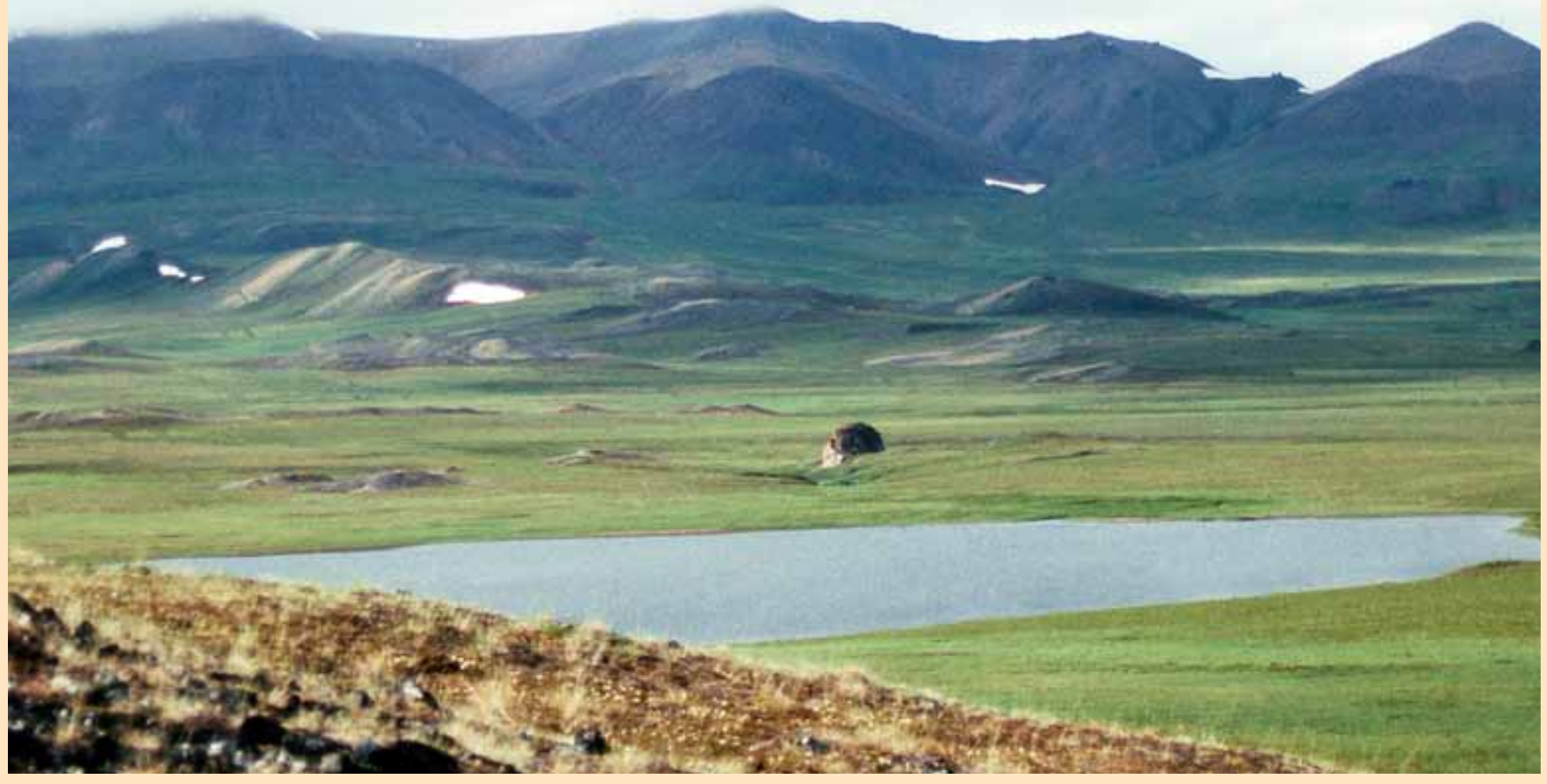

U.S. Department of the Interior

U.S. Geological Survey 
This page intentionally left blank 
Studies by the U.S. Geological Survey in Alaska, 2007

\section{The Longview/Lakeview Barite Deposits, Southern National Petroleum Reserve, Alaska (NPRA)—Potential-field Models and Preliminary Size Estimates}

By Jeanine M. Schmidt, Jonathan M.G. Glen, and Robert L. Morin

Prepared in cooperation with the U.S. Bureau of Land Management

Professional Paper 1760-C

U.S. Department of the Interior

U.S. Geological Survey 


\title{
U.S. Department of the Interior KEN SALAZAR, Secretary
}

\author{
U.S. Geological Survey \\ Suzette M. Kimball, Acting Director
}

U.S. Geological Survey, Reston, Virginia: 2009

This report and any updates to it are available online at:

http://pubs.usgs.gov/pp/1760/c/

For more information about the USGS and its products:

Telephone: 1-888-ASK-USGS (1-888-275-8747)

World Wide Web: http://www.usgs.gov/

Any use of trade, product, or firm names in this publication is for descriptive purposes only and does not imply endorsement by the U.S. Government.

Although this report is in the public domain, it may contain copyrighted materials that are noted in the text. Permission to reproduce those items must be secured from the individual copyright owners.

Produced in the Western Region, Menlo Park, California

Manuscript approved for publication, February 19, 2009

Text edited by Tracey Suzuki

Layout and design by Stephen L. Scott

Suggested citation:

Schmidt, J.M., Glen, M.G., and Morin, R.L., 2009, The Longview/Lakeview barite deposits, southern National Petroleum Reserve, Alaska (NPRA)—Potential-field models and preliminary size estimates, in Haeussler, P.J., and Galloway, J.P., Studies by the U.S. Geological Survey in Alaska, 2007: U.S. Geological Survey Professional Paper 1760-C, 29 p.

\section{FRONT COVER}

View southwestward from the southern outcrop of the Lakeview deposit across Lake 573 toward the Stack barite occurrence. The white and dark knob in the center midground is an outcrop of limestone informally named the Stack. Barite occurs in three low rubble and outcrop mounds a few meters to tens of meters north (to the right) of the limestone outcrop. 


\section{Contents}

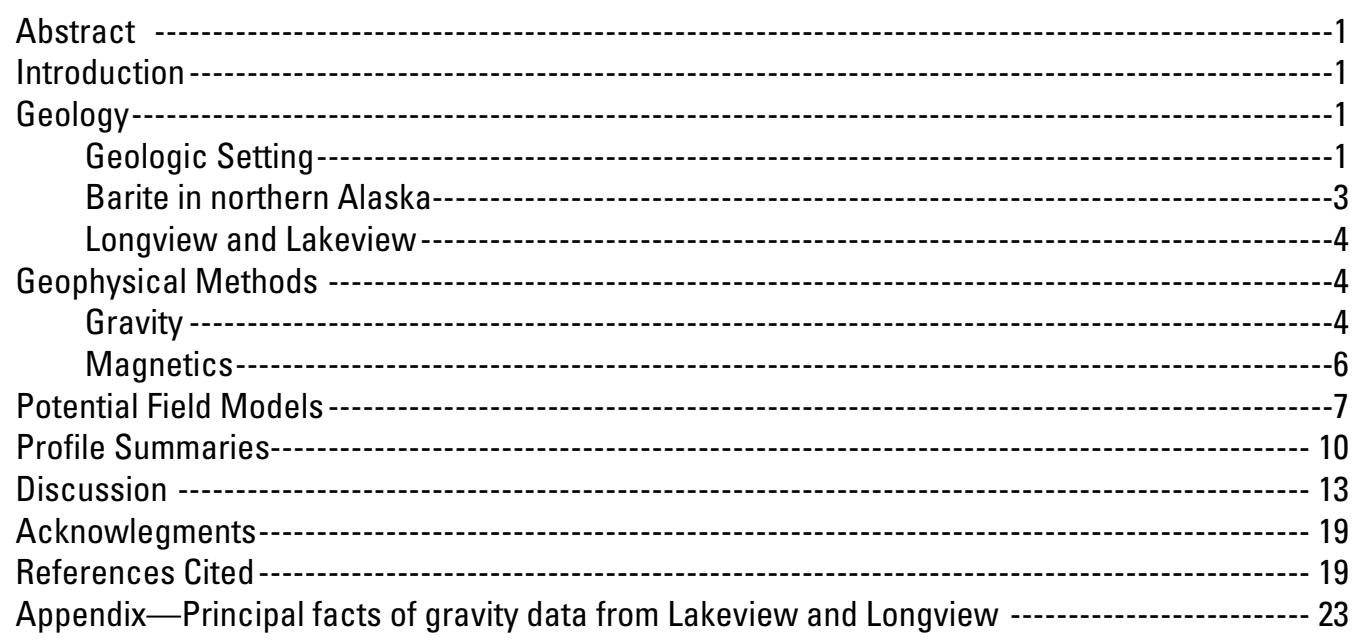

\section{Figures}

1. Shaded relief map of the southern National Petroleum Reserve, Alaska (SNPRA) --------2

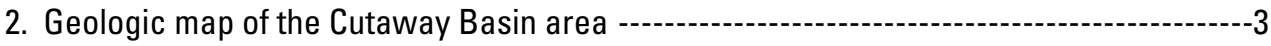

3. Topographic map of the Cutaway Basin (part of the Howard Pass C-3 quadrangle),

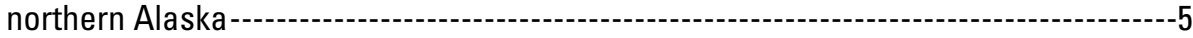

4. Shaded topographic relief map showing outcrops of barite and host lithologies at the Lakeview and Longview deposits, and cross structures inferred from geophysical data -

5. View of the Longview barite deposit, looking northeast from the southernmost

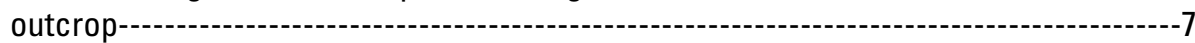

6. View of the Lakeview barite deposit, looking northeast from the southernmost outcrop----

7. Photograph of barite outcrop at the Lakeview deposit, showing pale gray weathering color and medium brown fresh surface --.--

8. Topographic map of the Longview/Lakeview area, showing locations of new gravity stations (white dots); outcrops of barite (pink polygons), and numbered profiles perpendicular (1-7) and parallel (8SW and 8NE) to strike of the barite

9. Regional isostatic gravity map of the Cutaway Basin area, showing location of new (colored dots) and previously collected (white dots) gravity stations ---.---.--9

10. Contoured isostatic gravity map of the Lakeview/Longview area, showing location of new gravity stations - 10

11. Potential field model along Profile 1 -

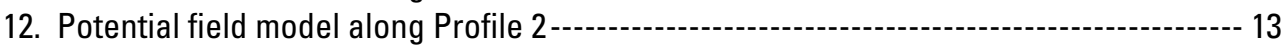

13. Potential field model along Profile 3--

14. Potential field model along Profile 4---:-

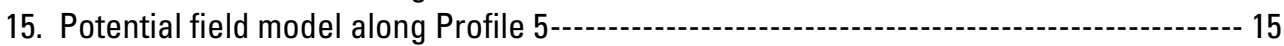

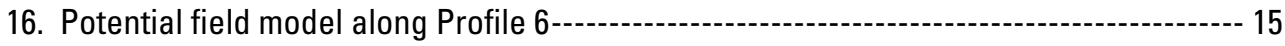

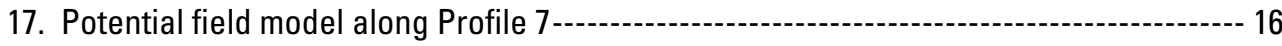

18. Geologic cross sections through the Longview barite deposit --

19. Geologic cross sections through the Lakeview deposit -

20. Potential field model along Profile 8NE --:-:- 18 
21. Potential field model along Profile 8SW

22. View southwestward from the southern outcrop of the Lakeview deposit across Lake 573 toward the Stack barite occurrence

\section{Tables}

1. Analytical data and estimated resources for Cutaway Basin barite deposits --------------6

2. Rock density measurements from the Lakeview and Longview deposits ---------------- 11

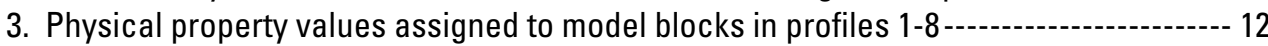

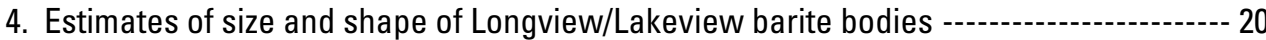




\title{
The Longview/Lakeview Barite Deposits, Southern National Petroleum Reserve, Alaska (NPRA)—Potential Field Models and Preliminary Size Estimates
}

\author{
By Jeanine M. Schmidt, Jonathan M.G. Glen, and Robert L. Morin
}

\section{Abstract}

Longview and Lakeview are two of the larger stratiform barite deposits hosted in Mississippian Akmalik Chert in the Cutaway Basin area (Howard Pass C-3 quadrangle) of the southern National Petroleum Reserve, Alaska (NPRA). Geologic studies for the South NPRA Integrated Activity Plan and Environmental Impact Statement process included an attempt to evaluate the possible size of barite resources at Longview and Lakeview by using potential-field geophysical methods (gravity and magnetics).

Gravity data from 227 new stations measured by the U.S. Geological Survey, sparse regional gravity data, and new, high-resolution aeromagnetic data were forward modeled simultaneously along seven profiles perpendicular to strike and two profiles along strike of the Longview and Lakeview deposits.

These models indicate details of the size and shape of the barite deposits and suggest thicknesses of 15 to $24 \mathrm{~m}$, and 9 to $24 \mathrm{~m}$ for the Longview and Lakeview deposits, respectively. Two groups of outcrops span $1.8 \mathrm{~km}$ of strike length and are likely connected below the surface by barite as much as $10 \mathrm{~m}$ thick. Barite of significant thickness $(\geq 5 \mathrm{~m})$ is unlikely to occur north of the presently known exposures of the Longview deposit. The barite bodies have irregular (nonplanar) bases suggestive of folding; northwest-trending structures of small apparent offset cross strike at several locations. Dip of the barite is 10 to $25^{\circ}$ to the southeast. True width of the bodies (the least certain dimension) is estimated to be 160 to $200 \mathrm{~m}$ for Longview and 220 to 260 $\mathrm{m}$ for Lakeview. The two bodies contain a minimum of 4.5 million metric tons of barite and more than 38 million metric tons are possible.

Grades of the barite are relatively high, with high specific gravities and low impurities. The potential for the Cutaway Basin to host economically minable quantities of barite is uncertain. Heavy-mineral concentrate samples from streams in the area, trace-element analyses, and physicalproperty measurements of bulk samples derived from trenching or drilling would be valuable for future assessment work.

\section{Introduction}

The northern foothills of the Brooks Range host a number of bedded barite deposits of relatively high quality and low silica and metal content (Kelley and others, 1993; fig. 1). Longview and Lakeview are two of the larger Mississippian stratiform barite deposits in the semicircular area known as Cutaway Basin (Howard Pass C-3 quadrangle) within the southern National Petroleum Reserve, Alaska (NPRA). These two deposits were discovered in 1992; sparse sampling indicated grades as high as 97.1 percent $\mathrm{BaSO}_{4}$ and specific gravities of up to $4.2 \mathrm{~g} / \mathrm{cc}$ (Kurtak and others, 1995). Preliminary studies (Kurtak and others, 1995) suggested that the barite bodies might lie along strike from one another over a $1.6 \mathrm{~km}$ distance and that they could be as much as $7.6 \mathrm{~m}$ (Lakeview) and $27 \mathrm{~m}$ (Longview) thick.

The Cutaway Basin area came under renewed study during development of the South NPRA Integrated Activity Plan and Environmental Impact Statement (IAP-EIS), a process which was begun by the U.S. Bureau of Land Management (BLM) in June 2005 and discontinued in May 2007. As part of the geologic studies for the EIS, the U.S. Geological Survey, in cooperation with BLM, attempted to evaluate the possible size of barite resources at Longview and Lakeview (Glen and others, 2006) by using potential-field geophysical methods (gravity and magnetics). This report summarizes the studies completed before the termination of the SNPRA EIS.

\section{Geology}

\section{Geologic Setting}

The southern NPRA comprises the northern foothills of the Brooks Range, a fold and thrust belt of Mesozoic age, which exposes rocks as old as Proterozoic (Moore and others, 1994). The lithologies and geologic units exposed in the NPRA (Gryc, 1988) are predominantly sedimentary rocks of Devonian to Cretaceous age. Recent interpretations of the structure (fig. 2; Dover and others, 2004) suggest a slight age difference between two sets of generally north-directed thrust 
faults, which juxtapose thin (meters to hundreds of meters) sheets of sedimentary rocks and interbedded, minor mafic flows and sills.

Geophysical and stratigraphic studies by the USGS (Saltus and others, 2001, 2002) indicate that basement rocks (below the structurally disrupted sedimentary sequence) thin and increase in density and magnetization southward across the NPRA. Cutaway Basin (fig. 1) overlies thinned, mafic-rich, normal- to high-density, strongly magnetic basement, which Saltus and others $(2001,2002)$ interpret as continental crust affected by tectonic extension (basement faulting) and mafic magmatism.

Above the basement rocks, the Lisburne Group of Mississippian to Permian age spans the entire length of the Brooks Range (Moore and others, 1994) and is a common unit in the fold and thrust belt. Although the Lisburne Group is predominantly carbonate rock, dark colored, deeper water facies (the "black Lisburne" of Tailleur and others, 1966) occur in the central Brooks Range and increase in volume and importance westward (Dumoulin and others, 1993, 1994, 2004). These deeper water facies comprise at least three mappable geologic units. The organic-carbon-rich Kuna Formation shale (Mull and others, 1982) hosts stratiform base-metal sulfide deposits (for example, Red Dog $\mathrm{Zn}-\mathrm{Pb}$ mine). Carbonate-turbidite slope-to-basin lithologies, informally called the Rim Butte unit (fig. 2; Dumoulin and others, 1993, 1994), are variably intruded by mafic sills of uncertain late Paleozoic to early Mesozoic age.
Siliceous rocks of the Akmalik Chert (fig. 2; Mull and others, 1982), which form the third recognized "black Lisburne" facies, host most of the barite deposits of the southern NPRA. The type section of the Akmalik (Mull and others, 1987 ) is thin (75 m) and comprised of well-bedded ( 2 to 75 $\mathrm{cm}$, average 7 to $8 \mathrm{~cm}$ ), pyritic black chert, with lesser siliceous black mudstone, interbedded with thin black shales and dolomitic limestone. On the basis of a plant fossil (Spicer and Thomas, 1987), radiolarians, and conodonts (Mull and others, 1987; Blome and others, 1998), the Akmalik Chert is Early (Osagean) to Late Mississippian (Meramecian) in age.

Rocks assigned to the Akmalik Chert within the SNPRA (Dumoulin and others, 1993, 1994; Dover and others, 2004) are generally dark gray to black, bedded radiolarian- or sponge spicule-rich cherts with trace pyrite. Locally, the cherts contain minor black siliceous shale partings and thin dolomitic or calcareous radiolarite beds; the latter are more abundant near sites of barite deposition (Dumoulin and others, 2004). Radiolarians are late Early Mississippian (Osagean) to Middle Pennsylvanian (Morrowan or Atokan) in age (Murchey and others, 1988; Dover and others, 2004); conodonts are late Early (Osagean) to Late Mississippian (Meramecian) in age (Dumoulin and others, 1993, 1994; Dover and others, 2004). The Akmalik Chert overlies Early Mississippian Kayak Shale at its type locality and regionally (Mull and others, 1982, 1987); its base is rarely exposed in the Cutaway Basin area. Its upper contact with Imnaitchiak Chert of the Etivluk Group is usually marked by a transition in chert color upward to red, green, or light gray.

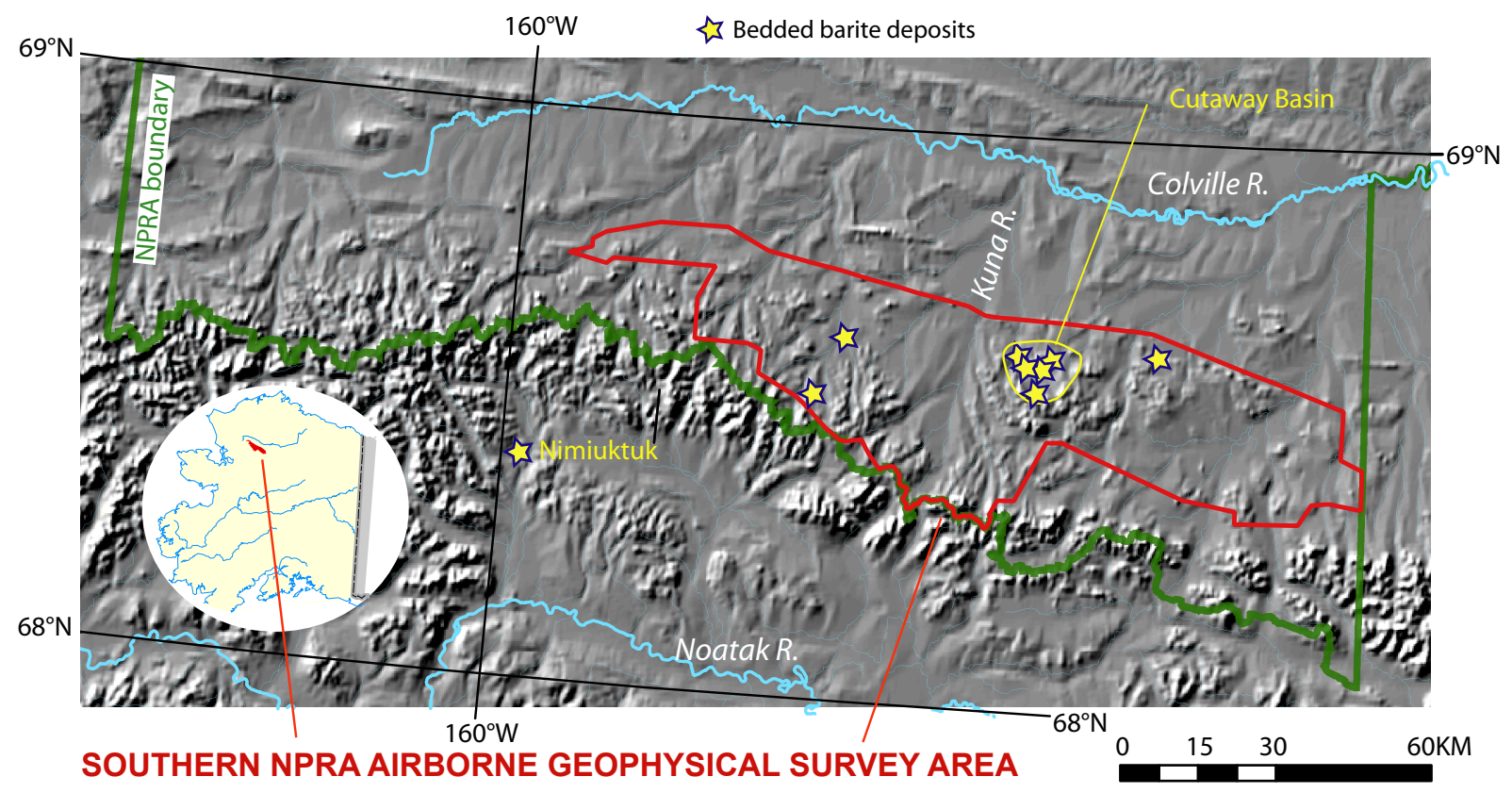

Figure 1. Shaded relief map of the southern National Petroleum Reserve, Alaska (SNPRA), indicating the location of bedded barite deposits and the area of the recent airborne resistivity and magnetic survey (Burns and others, 2006) 
The lack of clastic sediment and abundance of radiolarians relative to siliceous sponge spicules suggests that the Akmalik Chert was deposited in a sediment-starved basin, further from the continental margin than the Kuna Formation (Dumoulin and others, 1993; 1994; 2004) and spatially removed from the clastic input that produced turbidites of the Rim Butte unit.

\section{Barite in Northern Alaska}

Barite is an industrial commodity used as a pigment, a filler, a weighting agent in drilling muds, and as a source of barium. Barite deposits consist predominantly of the mineral barite $\left(\mathrm{BaSO}_{4}\right)$, whose whiteness and high specific gravity $(4.5 \mathrm{~g} / \mathrm{cc})$ are responsible for its usefulness. The purity of the barite, a measure of the intermixed silicate, carbonate, sulfide, other minerals, or other cations (for example, $\mathrm{Pb}, \mathrm{Sr}, \mathrm{Ca}$ ) in the barite structure, controls the quality of barite deposits. Barite for drilling mud applications requires a specific gravity of at least $4.2 \mathrm{~g} / \mathrm{cc}$; paint/filler grade materials must contain a minimum of 95 percent BaSO4 (Harben and Kuzvart, 1996).
The United States is heavily reliant (83 percent in 2007) on imports for its barite supply; some is produced domestically in Nevada and Georgia (Miller, 2008). The evaluation of potential domestic resources, such as those in southern NPRA, therefore, should include an assessment of quality, as well as tonnage.

Although barite occurs in some epigenetic veins and in residual surficial deposits, most global and domestic production comes from bedded (stratiform) syngenetic deposits within sedimentary rocks.

In the western part of the Brooks Range fold and thrust belt, barite is associated with some, but not all, sedimenthosted base-metal sulfide deposits in the Kuna Formation (Schmidt, 1997). Bedded barite that is not spatially associated with sulfides occurs in Mississippian to Triassic sedimentary rocks of the Lisburne and Etivluk Groups in the western and central Brooks Range (Schmidt, 1997), with a number of deposits concentrated in the Cutaway Basin area (fig. 1). The Nimiuktuk occurrence (fig. 1), south of NPRA, is hosted in black chert, black shale, and sandy limestone of Mississippian (?) age (Mayfield and others, 1979a, b). The Tuck, Bion, Stack, and Abby deposits of Cutaway Basin (fig. 3) are hosted

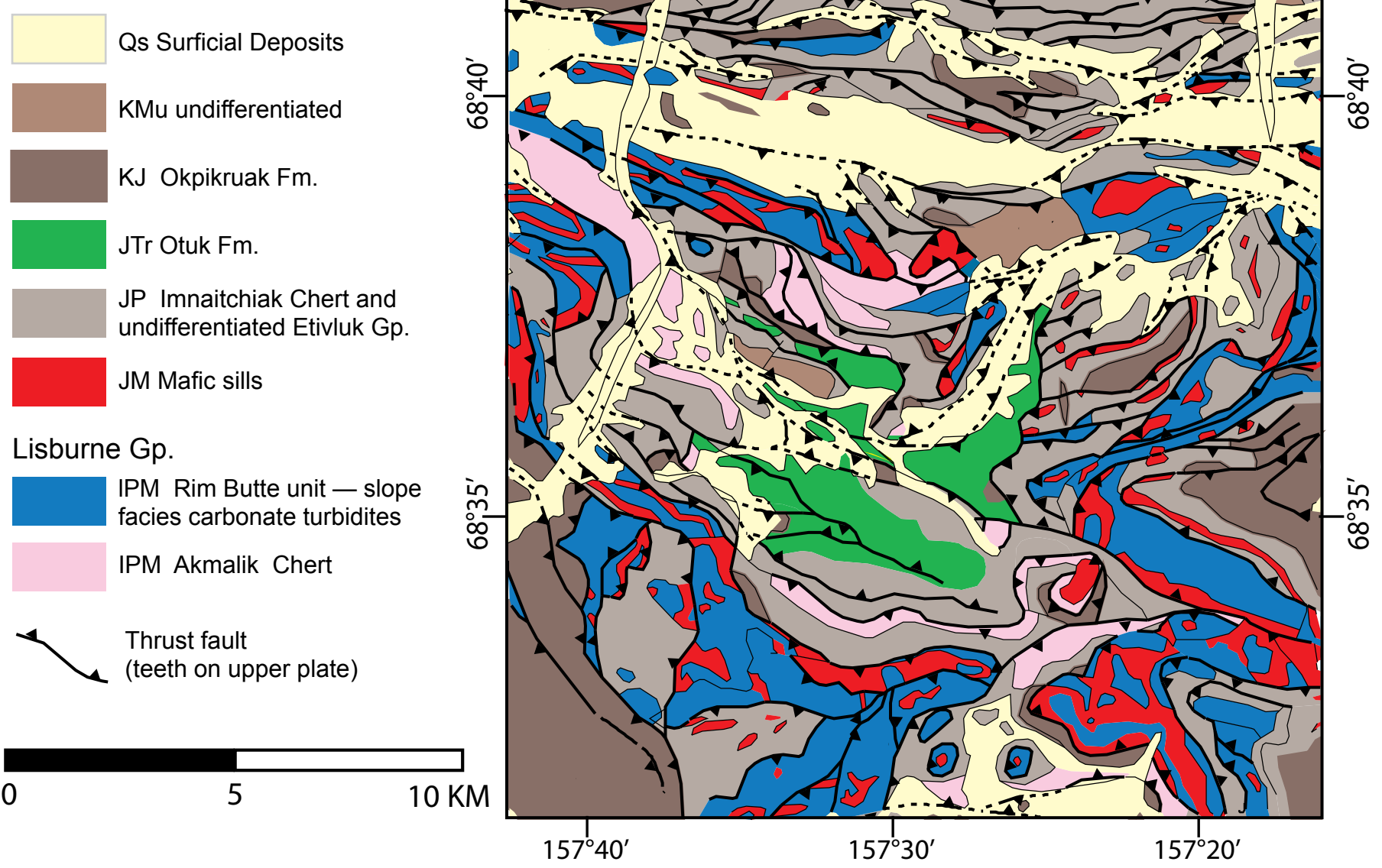

Figure 2. Geologic map of the Cutaway Basin area (modified from Dover and others, 2004). 
by black to dark gray cherts (Kelley and others, 1993; Kurtak and others, 1995), which are part of the Mississippian Akmalik Chert (Mull and others, 1987). Thin beds of limestone, calcareous turbidite, or petroliferous shale are locally present in the Akmalik near these barite occurrences.

The six Cutaway Basin deposits are generally exposed as low outcrops and rubble mounds in low-lying tundra. Barite is generally light to medium gray, fetid, medium to coarse grained, and equigranular; trace amounts of calcite may be present. Hydrocarbon specks occur in barite at Abby, Stack, and Lakeview (Schmidt, 1997). Lightweight pale gray shale with a very high total organic carbon content, and high uranium (19 ppm) and vanadium (143 ppm) contents, is exposed in rubble and small outcrops adjacent to the Stack deposit (Schmidt, 1997). Organic-rich limestone and shale are minor phases at Bion; petroliferous limestone occurs at the Ekakevik barite-witherite occurrence (Kelley and others, 1993) in dark gray cherts of the Lisburne Group $10 \mathrm{~km}$ northeast of Longview (in the Howard Pass C-2 quadrangle). The geologic setting of these deposits suggests that barite was deposited in a moderate to deep, restricted basin, with high carbon content and very little clastic input.

Preliminary chemical analyses, specific gravities, and resource estimates for the Cutaway Basin barite deposits (table 1) indicate that they are base-metal poor and very dense, suggesting very low contents of impurities such as sulfide, carbonate, and silicate minerals.

\section{Longview and Lakeview}

Longview and Lakeview are the names given to two sets of low-lying barite outcrops located along strike from one another, northeast of a small lake (elevation $573 \mathrm{ft} . ; 174.7 \mathrm{~m}$ ) (fig. 3) in Cutaway Basin (Kelley and others, 1993; Kurtak and others, 1995). The barite outcrops are structurally overlain by a thrust sheet of mafic sills and carbonate turbidites of the Rim Butte unit. These overlying lithologies form the erosionresistant arcuate hills within and outlining Cutaway Basin.

The Longview deposit (Kurtak and others, 1995) comprises the four northernmost outcrops and rubble mounds of barite (figs. 4, 5). Longview strikes approximately N $35-40^{\circ} \mathrm{E}$; dips of bedding in the barite are indicated as $60-70^{\circ} \mathrm{SE}$

(Kurtak and others, 1995), but the contact with overlying grayweathering black chert dips $45^{\circ}$ southeastward (J. Schmidt, this study). Folding of the sedimentary units or discordance between contacts and internal layering within the barite may explain the dip variations. Longview barite is pale to medium gray-brown on fresh surfaces (weathers pale to medium gray) and is medium- to coarse-grained, equigranular, fetid, and locally crosscut by $1-\mathrm{cm}$-wide veins of lighter-colored barite.

Lakeview is the name given to a series of outcrops (figs. 4,6 ) southwest of Longview which strike N $60^{\circ} \mathrm{E}$ (Kurtak and others, 1995). Local dips of barite bedding have been measured at $30^{\circ} \mathrm{NW}$ (J. Schmidt, this study), $21^{\circ} \mathrm{NE}$ (R. Morin, this study), $30^{\circ}$ SE (J.A. Dumoulin, USGS, written commun.,
2005 ) and $65^{\circ} \mathrm{SE}$ (Kurtak and others, 1995; R. Morin, this study). Folding of the sedimentary units or possible discordance between barite contacts and internal layering may account for the dip variations. Pale gray-weathering dark gray chert which hosts the deposit is radiolarian-rich, contains some spiculitic layers, and is locally veined by silica and brecciated, but nowhere contains barite. Lakeview barite weathers pale to medium gray and is fetid, medium grained, equigranular, and mottled to locally banded white, light gray, tan, green or brown (fig. 7) on fresh surfaces. It locally contains small black specks of hydrocarbons.

\section{Geophysical Methods}

Geophysical potential-field methods produce an image of subsurface features that reflects lateral and vertical contrasts in rock density and magnetic properties (induced and remanent magnetizations). Rock-property contrasts may occur within a geologic unit, such as across a facies change, at geologic structures (such as faults or folds), or at contacts between lithologic units. The geometry of and depth to a possible source, the character of the gravity and geomagnetic fields, and the physical properties of the potential source rocks combine to produce the potential-field anomaly. Despite the complexity of measuring and modeling potential fields, gravity and magnetic data can be effectively used to resolve the geometry and origin of specific rock bodies.

\section{Gravity}

The large density contrast between bedded barite and its host rocks (shales, chert, and limestone) makes gravity an especially useful method to constrain the extent, shape, size, and relative quality of barite deposits in northern Alaska. The Nimiuktuk barite occurrence with a 10 × 50 × 80 m outcrop dimension produced an approximately $2 \mathrm{mGal}$ gravity anomaly (Barnes and others, 1982) and was interpreted to contain $>1.3$ million metric tons of barite. Barite at Abby produced a $1 \mathrm{mGal}$ gravity anomaly (Kelley and others, 1993; Morin, 1997); dips of 25 to $35^{\circ}$ southward and a maximum thickness of about 25 $\mathrm{m}$ were estimated from the detailed gravity profiles. The Bion barite occurrence produced about a 1.2 to $1.4 \mathrm{mGal}$ gravity anomaly and was modeled (Morin, 1997) as a relatively flatlying sheet 10 to $30 \mathrm{~m}$ thick.

New gravity measurements (appendix) were collected with a LaCoste and Romberg G model gravimeter in 2005 at 227 stations (10-70 m apart) along 9 profiles through the Longview and Lakeview exposures (figs. 3, 8). Gravity data for the modeled profiles in this study were drawn from grids generated from several sources: existing regional data (figs. 3, 9), including data collected along widely spaced seismic lines during early NPRA exploration (Beaty and others, 2006), and these new, closely spaced data. Data were collected along seven profiles (fig. 8) that crossed at a high angle to the strike of the deposits and their 
enclosing host rocks; two other profiles (8SW and 8NE, fig. 8) were oriented along strike. Along all profiles, data collection extended beyond the previously mapped exposures of barite. Elevation data were collected at each new gravity station by using a Trimble 4400 GPS instrument having a vertical precision of about 1.5 centimeter, depending on the substrate.

To obtain gravity data that reflect lateral variations in crustal density, raw gravity measurements were processed by using standard methods (Dobrin and Savit, 1988; Blakely, 1995) that remove the effects of elevation and topography and the mass, rotation, and ellipsoidal shape of the Earth, yielding the complete Bouguer gravity anomaly (CBA). Although the CBA reveals lateral density variations at short wavelength scales, it does an inferior job of identifying longer wavelength features, which are often masked by broad anomalies from crustal roots that isostatically compensate topographic loads. An additional correction for the effects of compensating masses results in maps of isostatic gravity (figs. 9, 10). The scarcity of regional data (fig. 3) in the Cutaway Basin area means that large-scale, regional isostatic anomalies (fig. 9) are poorly constrained.

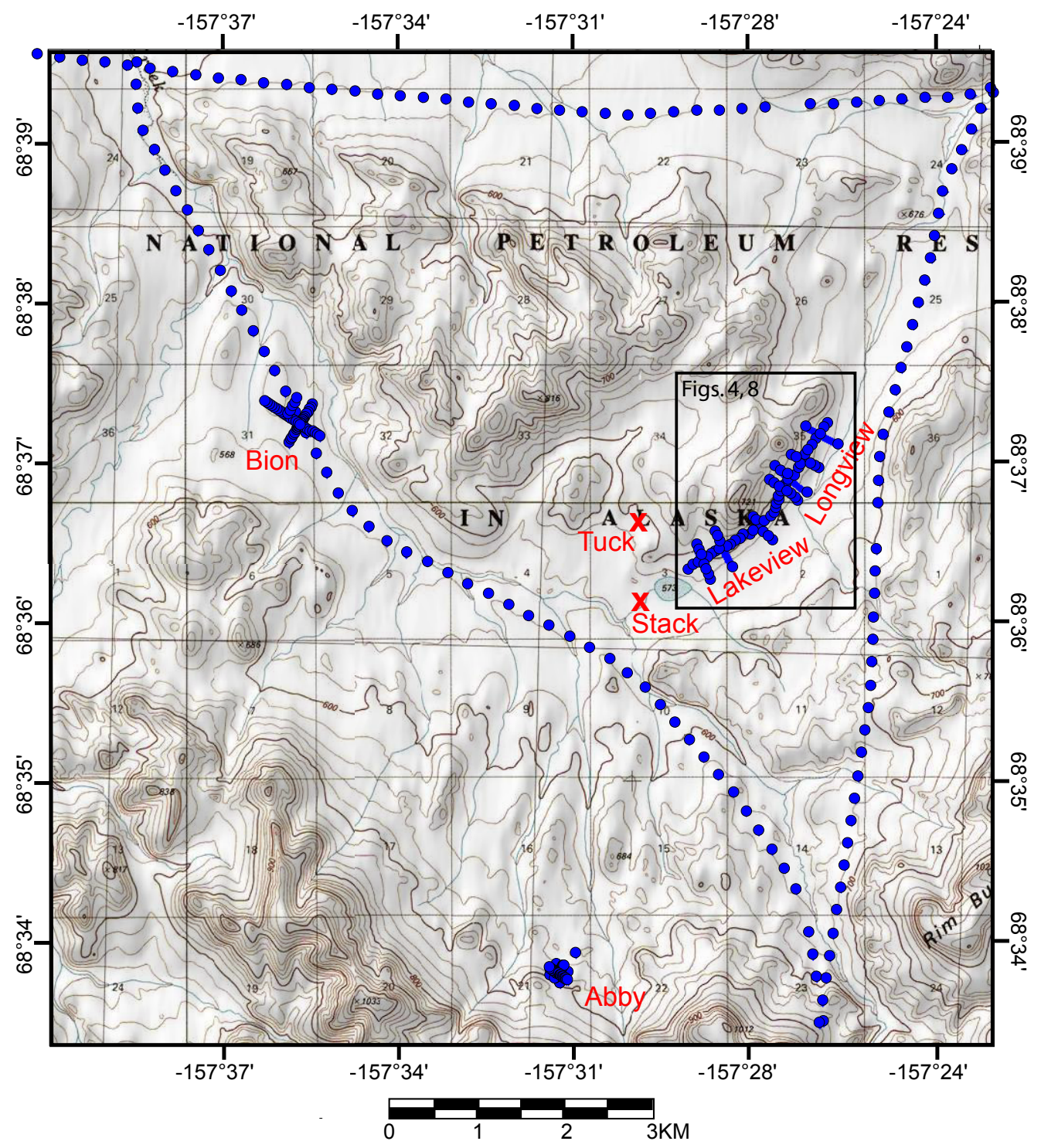

Figure 3. Topographic map of the Cutaway Basin (part of the Howard Pass C-3 quadrangle), northern Alaska, indicating the location of the Bion, Tuck, Stack, Abby, Longview, and Lakeview barite deposits. Blue dots indicate locations of all gravity measurements including Abby and Bion (Morin, 1997), this study (Lakeview and Longview) and regional gravity data (Beaty and others, 2006). Deposits are indicated by clusters of blue dots (for example, Abby) or by red x's where no gravity data have been obtained. 
Table 1. Analytical data and estimated resources for Cutaway Basin barite deposits.

\begin{tabular}{|c|c|c|c|c|}
\hline & $\begin{array}{c}\text { Mean } \\
\text { specific } \\
\text { gravity }\end{array}$ & $\mathrm{BaSO}_{4}$ content & Base metal content & $\begin{array}{l}\text { Estimated } \\
\text { indicated } \\
\text { resources }\end{array}$ \\
\hline Abby & $4.23(n=30)$ & $87.2-96.2 \%(n=4)$ & $19 \mathrm{ppm} \mathrm{Zn},<9 \mathrm{ppm} \mathrm{Pb}(\mathrm{n}=4)$ & $0.41 \mathrm{Mt}$ \\
\hline Stack & $4.27(\mathrm{n}=67)$ & $93.7-97.4 \%(\mathrm{n}=3)$ & $3 \mathrm{ppm} \mathrm{Zn},<7 \mathrm{ppm} \mathrm{Pb}(\mathrm{n}=3)$ & $2.85 \mathrm{Mt}$ \\
\hline Bion & $4.27(n=7)$ & $93.1-99.9 \%(\mathrm{n}=7)$ & $16 \mathrm{ppm} \mathrm{Zn},<34 \mathrm{ppm} \mathrm{Pb}(\mathrm{n}=7)$ & $10.05 \mathrm{Mt}$ \\
\hline Tuck & $3.9 \quad(n=2)$ & $95.0-96.8 \%(\mathrm{n}=2)$ & 5 ppm $\mathrm{Zn},<2 \mathrm{ppm} \mathrm{Pb}(\mathrm{n}=2)$ & $0.16 \mathrm{Mt}$ \\
\hline Lakeview & $4.0(n=4)$ & $95.1-96.7 \%(\mathrm{n}=4)$ & $<53$ ppm $\mathrm{Zn},<2 \mathrm{ppm} \mathrm{Pb}(\mathrm{n}=4)$ & $3.77 \mathrm{Mt}$ \\
\hline Longview & $3.9(n=6)$ & $93.8-97.1 \%(\mathrm{n}=6)$ & $<43 \mathrm{ppm} \mathrm{Zn,} \mathrm{<6} \mathrm{ppm} \mathrm{Pb}(\mathrm{n}=6)$ & $29.5 \mathrm{Mt}$ \\
\hline
\end{tabular}

The isostatic gravity maps illustrate contrasts in crustal density. Short-wavelength anomalies with steep gradients must originate from sources at shallow depths. Long-wavelength anomalies with smooth gradients most often originate from deeply buried sources but can be produced by shallow, thin sources with gently sloped sides and large lateral extent. Mafic and ultramafic igneous rocks, metamorphic rocks, and barite are dense and generally associated with gravity highs; gravity lows indicate lower density volcanic and sedimentary rocks.

\section{Magnetics}

Variations in the earth's magnetic field result from contrasts in the magnetic properties of rocks, which in turn reflect crustal structures, lithologic contacts, or variations in metamorphism, alteration, remanent magnetization, or mineralogy of magnetic materials in different rock units. Magnetic field strength depends on both induced and remanent crustal magnetization. Although the magnitude of remanence is often
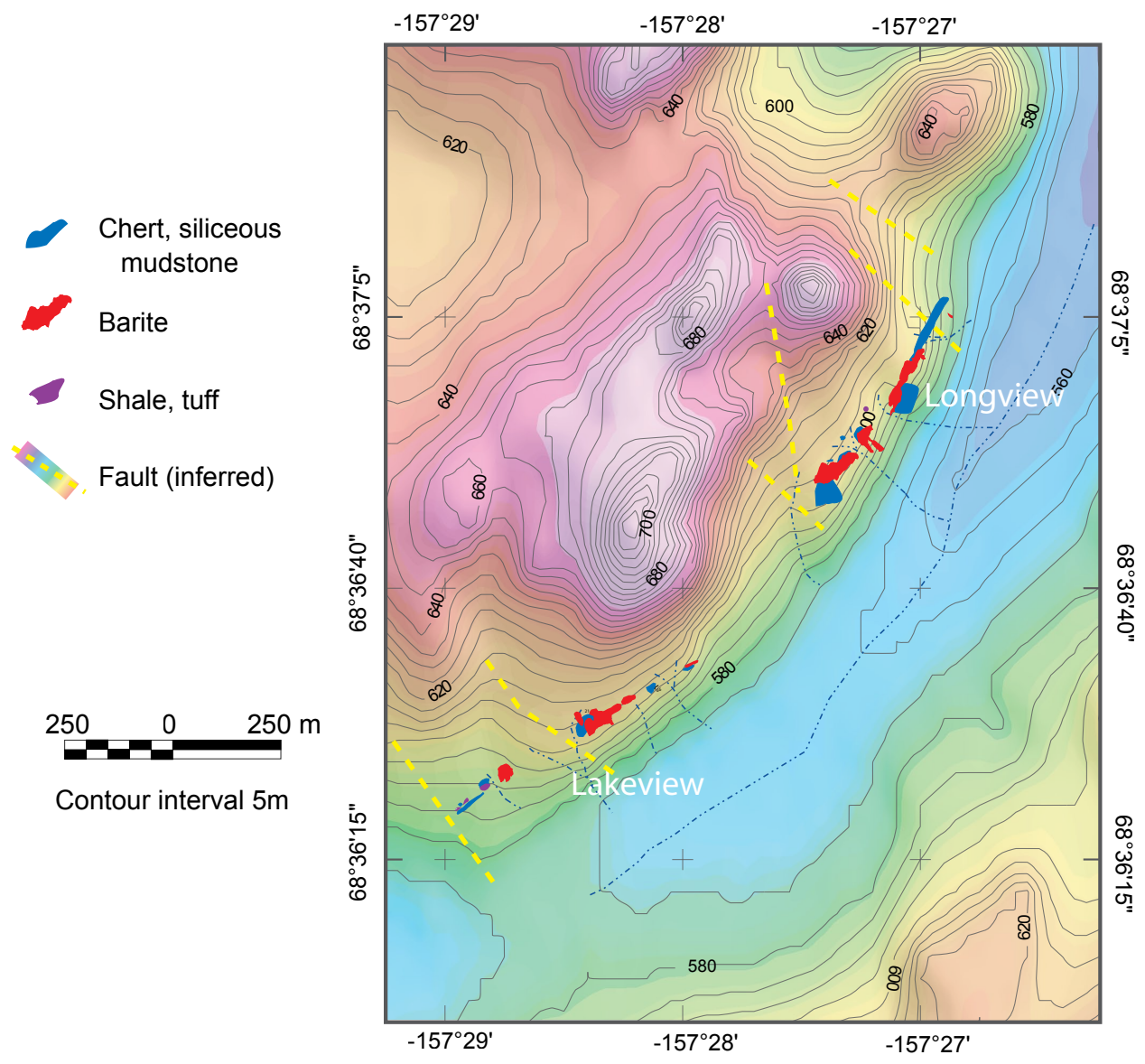

Figure 4. Shaded topographic relief map showing outcrops of barite and host lithologies at the Lakeview and Longview deposits, and cross structures inferred from geophysical data. 


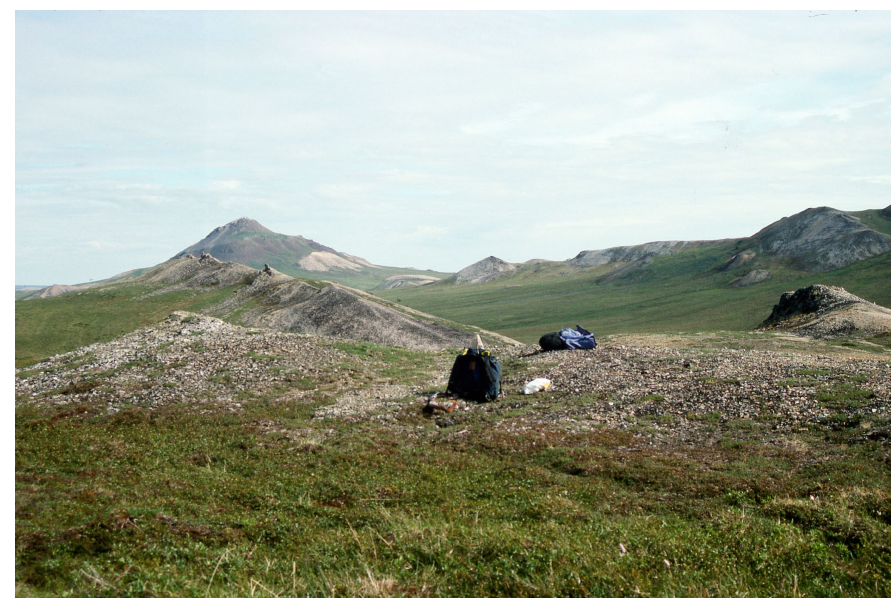

Figure 5. View of the Longview barite deposit, looking northeast from the southernmost outcrop. Apparent dips are shallow to the ESE (right side of photo). Reddish brown and cream-colored rocks in the left background are the distinctive colors of the Rim Butte unit mafic sills and calcareous turbidites, respectively, in overlying thrust sheets. Pack in foreground is approximately $60 \mathrm{~cm}$ tall; barite spires along ridgecrest in mid-ground are approximately $2 \mathrm{~m}$ high.

negligible, and its orientation often mimics the induced field direction, it can in some cases have a significant effect, particularly in strongly magnetic units such as mafic and ultramafic rocks.

The character of magnetic anomalies directly reflects the depth to the magnetic source. The shallower a source, the higher the amplitude, the shorter the wavelength, and the steeper the gradients of its anomaly. Magnetic highs generally result from mafic igneous and some crystalline igneous and metamorphic rocks; lows are more commonly produced by felsic igneous, sedimentary, or altered crystalline rocks.

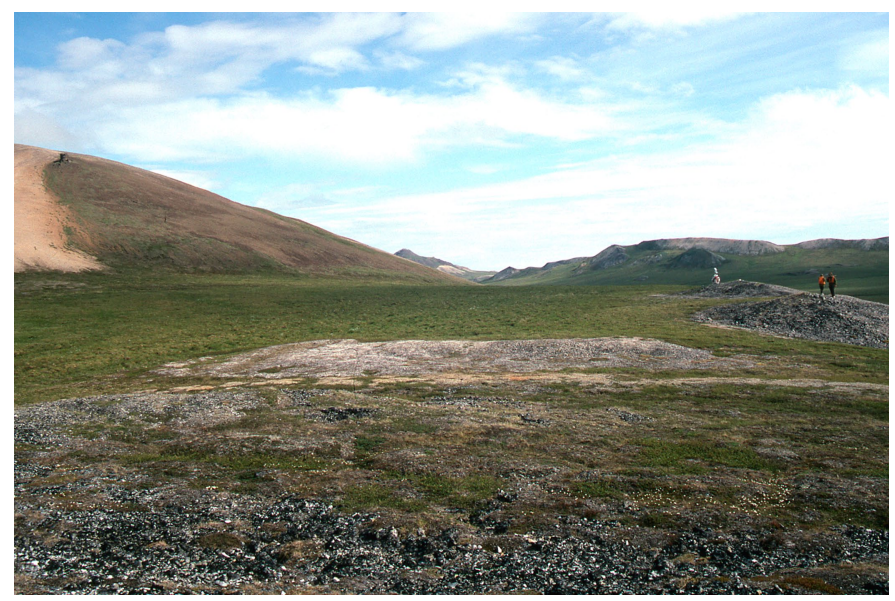

Figure 6. View of the Lakeview barite deposit, looking northeast from the southernmost outcrop. Gray rubble in foreground is Akmalik Chert host.
Magnetic data for this study were obtained from regional aeromagnetic surveys (Saltus and Simmons, 1997) and a recent high-resolution helicopter-borne combined magnetic and resistivity survey (fig. 1; Burns and others, 2006) acquired by the BLM as part of the SNPRA IAP-EIS process. The helicopter-borne survey was draped at $100 \mathrm{ft}(30.5 \mathrm{~m})$ above ground level with flight lines oriented northeast-southwest and

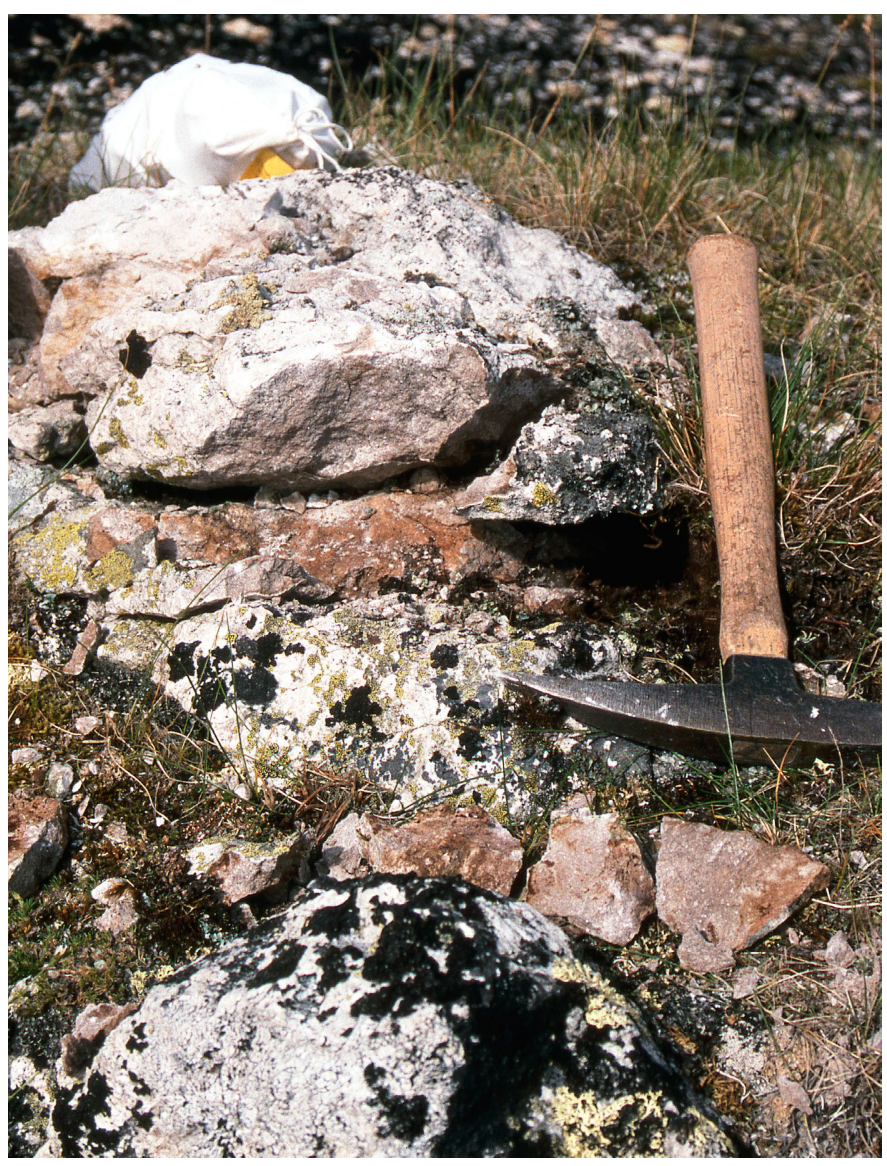

Figure 7. Photograph of barite outcrop at the Lakeview deposit, showing pale gray weathering color and medium brown fresh surface. Rock hammer is approximately $35 \mathrm{~cm}$ in length.

spaced $0.4 \mathrm{~km}$ apart over the study area. Profiles for the potential-field modeling at Longview and Lakeview were pulled from a grid of these data.

\section{Potential-field Models}

Simultaneous forward modeling of gravity and magnetic data along profiles was performed using the Geosoft GM-SYS software program, which can accept profiles that are not orthogonal to strike. Forward modeling of this type (Talwani and others, 1959; Blakely and Connard, 1989) provides important constraints to the structural geology of a region and, in 
this case, provides more rigorous estimates of the extent and thickness of concealed barite.

Profiles for this study were chosen to maximize use of the new gravity data. Seven profiles (1 to 7) are roughly perpendicular to the NNE strike of geologic units; two profiles (8SW and $8 \mathrm{NE}$ ) are approximately parallel to strike. Profile models are produced by defining bodies (that is, lithologic blocks), assigning densities and magnetic susceptibilities to them and iteratively adjusting their properties and orientation until the modeled gravity and magnetic susceptibility curves (calculated anomalies) most closely match the observed data. For all profiles, consistent physical properties are assigned to all blocks of a given lithology. To improve the accuracy of the modeling, specific-gravity values assigned reflect those of rock samples from the Cutaway Basin area (table 2) where available. Otherwise, assigned values (table 3) were derived from regional (western United States; Nazarova and Glen, 2004) or global averages for similar lithologies. Only four lithologic groups were modeled in these profiles: barite (the only dense lithology), Akmalik Chert, mafic sills (the only magnetic lithology), and Rim Butte unit carbonate. Slivers of Permian to Cretaceous clastic sedimentary rocks, although not exposed in any significant amounts in the immediate Lakeview/Longview area, may occur between the modeled lithologies; their physical properties would be most similar to those of the Rim Butte carbonate.

Model magnetic fields were calculated on a datum that drapes topography at a nominal height of $100 \mathrm{ft}(30.5 \mathrm{~m})$, which reflects the average elevation of the recent airborne survey. Model bodies' magnetizations were assumed to parallel the present field direction, effectively reflecting induced magnetizations acquired in a field of $57016 \mathrm{nT}, 79^{\circ}$ inclination, and $19^{\circ}$ declination. No attempt was made to assign remanent magnetizations to any of the model source bodies.

Potential-field models are inherently nonunique. They are most effective at constraining the depth to the top of an anomaly's source, and the location and dip of its edges, but are relatively insensitive to the depth of a source's base. Uncertainty in the final models is the result of four main factors. First, regional gravity gradients (which control the overall slope of the observed data curve) are poorly defined in the Cutaway Basin area because the regional gravity data from which they are derived are sparse and not uniformly distributed (figs. 3,

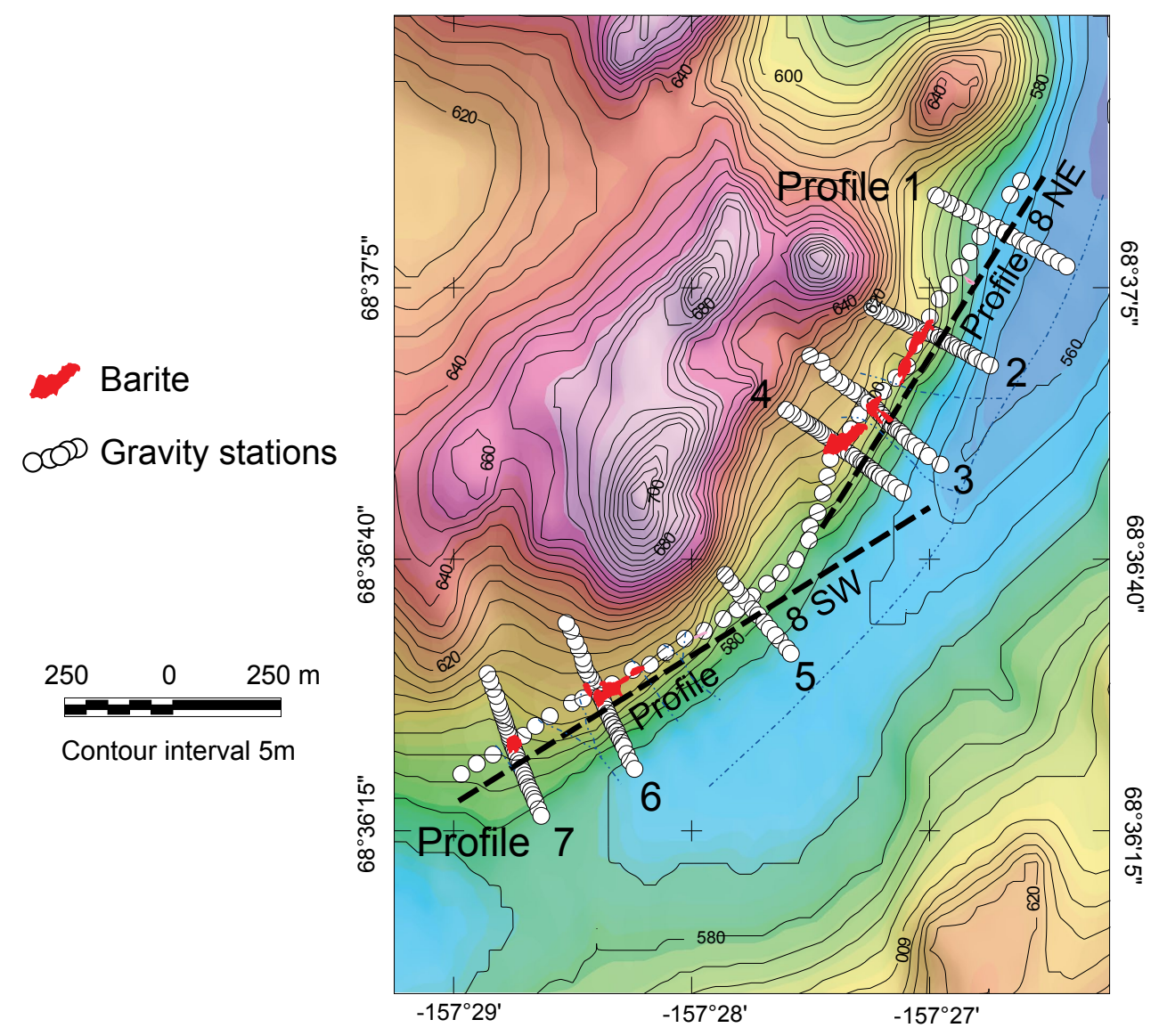

Figure 8. Topographic map of the Longview/Lakeview area, showing locations of new gravity stations (white dots); outcrops of barite (pink polygons), and numbered profiles perpendicular (1-7) and parallel (8SW and $8 \mathrm{NE}$ ) to strike of the barite. 
9). Second, there are discrepancies in the measured elevations between the new gravity stations (measured with a GPS instrument with vertical precision of approximately $1.5 \mathrm{~cm}$ ) and the older regional-gravity data, whose vertical accuracy is estimated at approximately $1 \mathrm{~m}$. Third, variable tundra cover limits the accuracy of geologic mapping, and fourth, the local geology is extremely complex with numerous thin (<tens of meters) thrust sheets, which increases the uncertainty in projecting individual lithologic units over any great distance or depth.

In the modeling process, bodies are initially designated as tabular horizontal prisms with their longest axis perpendicular to the profile. The extent of the bodies in the third dimension, in and out of the plane of the section, are set by using geologic limits along strike of a unit. This produces the " $3 / 4$ " aspect of the $23 / 4$ dimensional models (versus older 2D-modeling methods in which the 3 rd dimension is assumed to be infinite). The surface geometry of model bodies is constrained by structural measurements and lithologic contacts from unpublished mapping (J. Schmidt and J. Dumoulin, USGS), previous maps (Kelley and others, 1993; Kurtak and others, 1995), and the perimeter of exposed barite rubble (figs. 4, 8) mapped in this study by using a Garmin handheld GPS with a horizontal accuracy of approximately $2 \mathrm{~m}$. Where lithologies (including barite) have been modeled at the surface in areas where no outcrop or rubble are known, we assume that these units lie beneath a thin tundra cover.

Subsurface geometry (block shape, orientation, and location) of the anomaly sources is more difficult to constrain, particularly for sources with no surface exposure (buried). The maximum horizontal gradients (MHG) of potential-field data tend to lie over the edges of bodies with near vertical boundaries (Grauch and Cordell, 1987; Cordell and McCafferty, 1989). MHGs highlight abrupt lateral changes in density or magnetization, and are used to estimate the extent (edges) of buried sources. The slope of the observed data limits the possible orientations of the source, and the shape and height of the observed data curve constrain the thickness of the source.

After adjusting block (source) geometry and properties to match all geologic constraints within a given profile, the source body depths, dips, and properties were adjusted to be consistent at all crossing points between profiles (for example, intersection of $8 \mathrm{SW}$ and 5,6, and 7 in figure 8). When com-
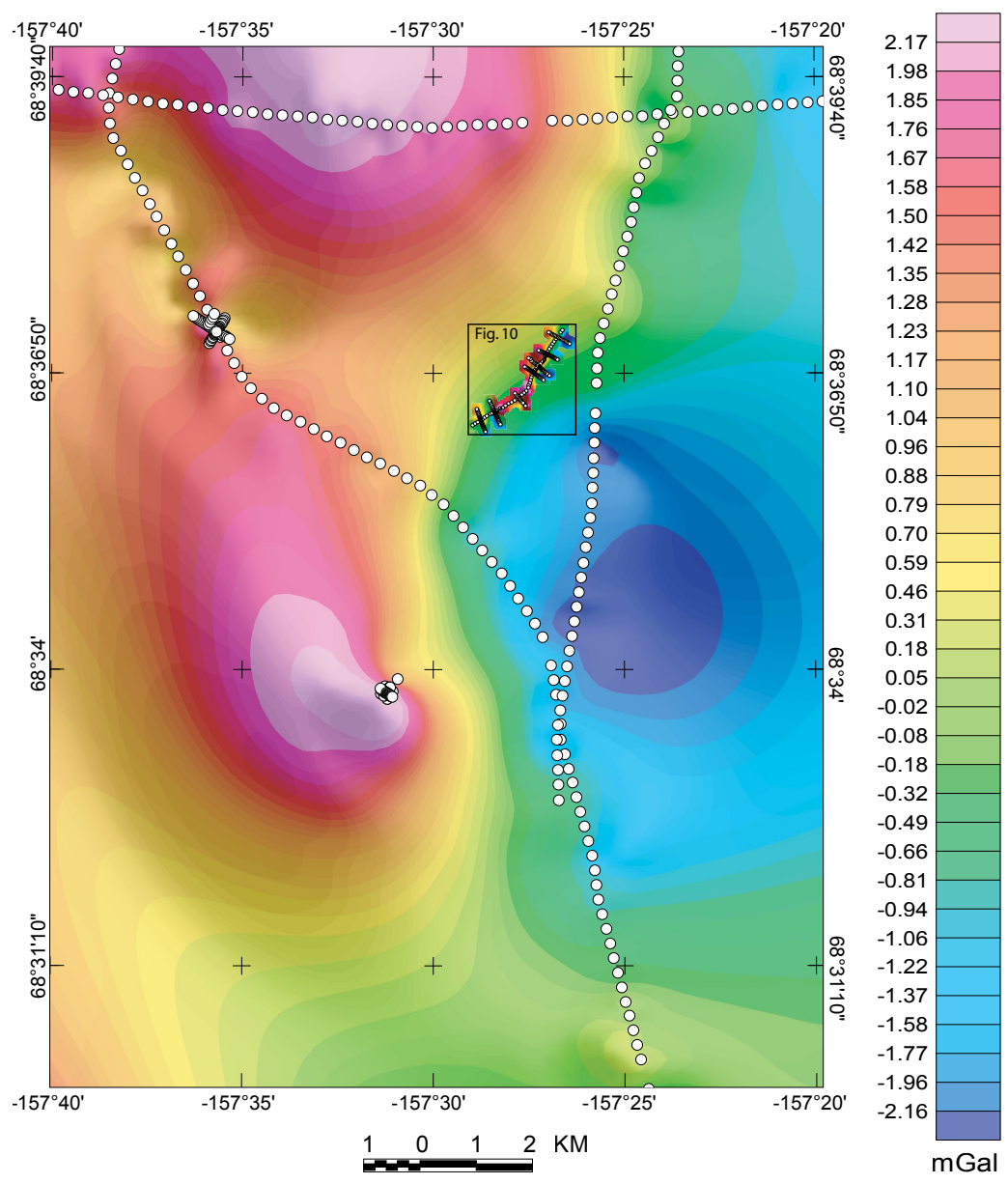

Figure 9. Regional isostatic gravity map of the Cutaway Basin area, showing location of new (colored dots) and previously collected (white dots) gravity stations. 

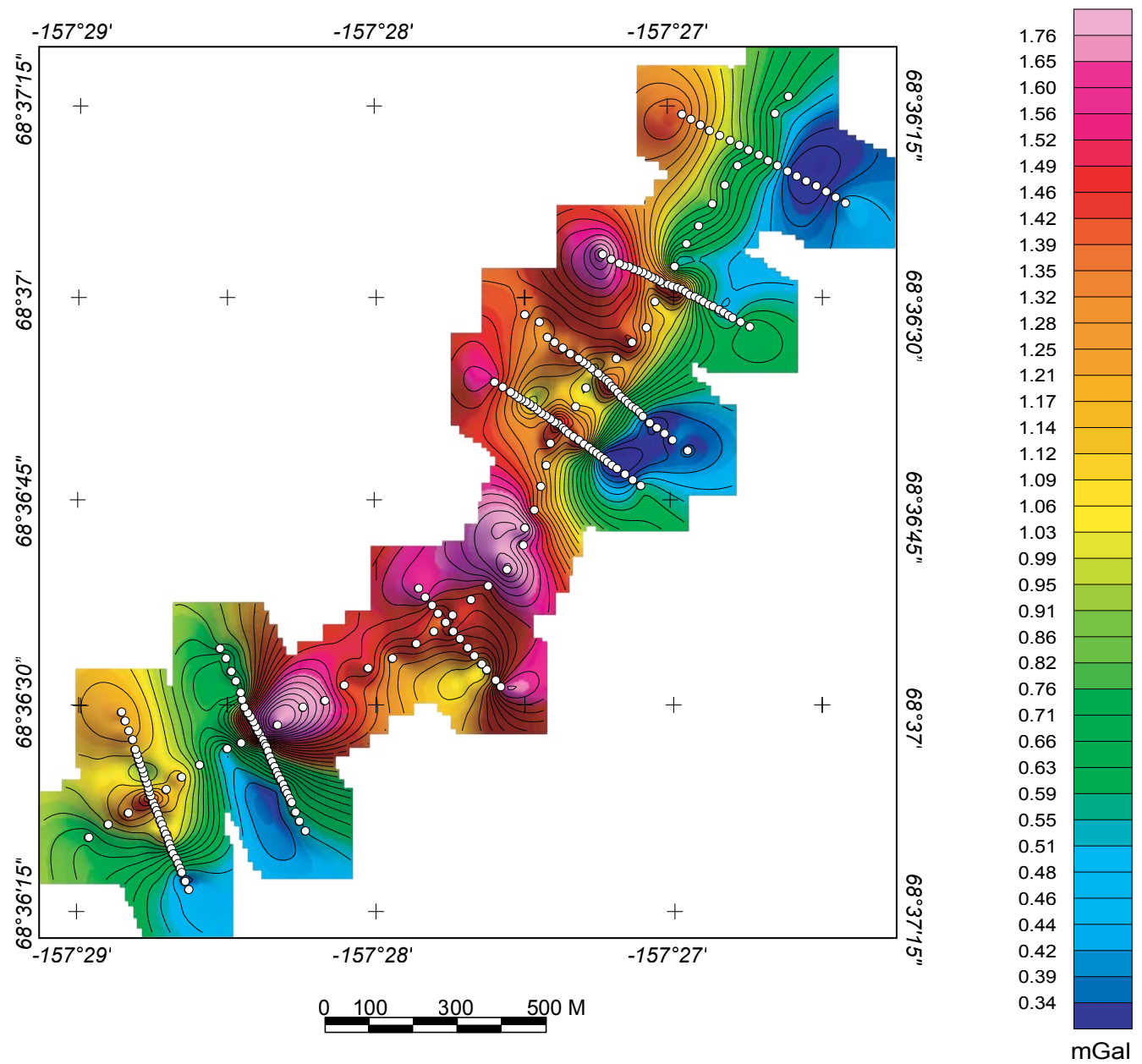

Figure 10. Contoured isostatic gravity map of the Lakeview/Longview area, showing location of new gravity stations (white dots).

plete, these $23 / 4-\mathrm{D}$ models represent the overall configuration of rock bodies that most closely accounts for the observed gravity and magnetic data. The final profiles approximate simplified geologic cross sections and indicate new details about the size, shape, and orientation of the Longview and Lakeview barite deposits.

\section{Profile Summaries}

The models derived along each profile are presented and briefly described here. Profile 1 (figs. 8, 11) lies north of the Longview barite outcrops; its geophysical expression is the most equivocal of all the profiles in this study. Although the presence of a thin layer of barite (as indicated in figure 11) cannot be ruled out, overall, gravity values are much lower than along the other profiles and barite of significant thickness $(\geq 3 \mathrm{~m}$ ) is unlikely to occur. Observed magnetic values along profile 1 increase to the southeast, a gradient opposite to that along nearby parallel profiles. This gradient could not be reproduced in the model by using rock types and dips known from the area and may suggest significant, previously unknown, variations in the volume and thickness of mafic sills in thrust sheets underlying the Akmalik Chert.

Three profiles (2, 3, and 4; fig. 8) crosscut the Longview barite deposit (figs. 12-14) from north to south. The models developed along these three profiles are similar, suggesting a consistent orientation and continuity of units along strike. These three models indicate a barite body as much as 24 $m$ thick and suggest that the base of the barite is nonplanar and highly irregular in form. This shape may be the result of folding of originally bedding-parallel barite lenses during northward emplacement of thrust sheets. Dips of individual barite/chert contacts vary widely and include flat and gently north-dipping surfaces. The overall dip of the barite body at Longview is modeled as 10 to $25^{\circ}$ to the southeast, significantly less than the $60^{\circ}$ dips suggested from measurements of apparent bedding in outcrop. Profile 3 (fig. 13) provides 
Table 2. Rock density measurements from the Lakeview and Longview deposits.

[DBD, dry bulk density; GD, grain density; SBD, saturated bulk density]

\begin{tabular}{|c|c|c|c|c|c|c|c|c|c|}
\hline & \multirow{2}{*}{ Rock Type } & \multirow{2}{*}{$\begin{array}{l}\text { Sample ID } \\
\text { Longview }\end{array}$} & \multicolumn{2}{|c|}{ Latitude (N) } & \multicolumn{2}{|c|}{ Longitude (W) } & \multirow{2}{*}{$\begin{array}{c}\text { GD, in } \\
\text { g/cc } \\
4.28\end{array}$} & \multirow{2}{*}{$\begin{array}{c}\text { SBD, } \\
\text { in } \\
\text { g/cc } \\
4.19\end{array}$} & \multirow{2}{*}{$\begin{array}{c}\text { DBD, } \\
\text { in } \\
\text { g/cc } \\
4.17\end{array}$} \\
\hline & & & 68 & 36.909 & 157 & 27.246 & & & \\
\hline & Barite & 05B002 & 68 & 37.024 & 157 & 27.021 & 4.29 & 4.28 & 4.28 \\
\hline & Barite & $05 \mathrm{~B} 003$ & 68 & 36.986 & 157 & 27.070 & 4.21 & 4.13 & 4.11 \\
\hline & Barite & $05 \mathrm{~B} 004$ & 68 & 36.964 & 157 & 27.100 & 4.22 & 4.13 & 4.10 \\
\hline & Barite & $05 \mathrm{~B} 005$ & 68 & 36.914 & 157 & 27.224 & 4.22 & 4.07 & 4.02 \\
\hline & Barite & 05B008 & 68 & 36.844 & 157 & 27.376 & 4.27 & 4.2 & 4.18 \\
\hline & Barite & $05 B 009$ & 68 & 36.868 & 157 & 27.324 & 4.22 & 4.16 & 4.14 \\
\hline & Barite & $05 \mathrm{~B} 013$ & 68 & 36.390 & 157 & 28.738 & 4.21 & 4.12 & 4.09 \\
\hline & Barite & $05 \mathrm{~B} 015$ & 68 & 36.465 & 157 & 28.427 & 4.33 & 4.27 & 4.25 \\
\hline & Barite & $05 \mathrm{~B} 016$ & 68 & 36.459 & 157 & 28.385 & 4.24 & 4.14 & 4.11 \\
\hline & Barite & $05 \mathrm{~B} 017$ & 68 & 36.471 & 157 & 28.337 & 3.68 & 3.56 & 3.51 \\
\hline \multirow{11}{*}{ Mean: } & Barite & 05B019 & 68 & 36.496 & 157 & 28.228 & $\begin{array}{l}4.21 \\
\mathbf{4 . 2 0}\end{array}$ & $\begin{array}{l}4.08 \\
\mathbf{4 . 1 1}\end{array}$ & $\begin{array}{l}4.04 \\
\mathbf{4 . 0 8}\end{array}$ \\
\hline & Chert & 05B001 & 68 & 37.112 & 157 & 26.863 & 2.62 & 2.57 & 2.53 \\
\hline & Chert & $05 \mathrm{~B} 011$ & 68 & 36.360 & 157 & 28.813 & 2.56 & 2.55 & 2.54 \\
\hline & Chert & $05 \mathrm{~B} 012$ & 68 & 36.383 & 157 & 28.786 & 2.58 & 2.52 & 2.49 \\
\hline & Chert & $05 B 014$ & 68 & 36.442 & 157 & 28.491 & 2.58 & 2.56 & 2.55 \\
\hline & Chert & 05B018 & 68 & 36.481 & 157 & 28.268 & 2.56 & 2.53 & 2.52 \\
\hline & Chert & $05 \mathrm{~B} 020$ & 68 & 36.523 & 157 & 28.071 & 2.59 & 2.57 & 2.57 \\
\hline & Limestone or chert & $05 \mathrm{~B} 006$ & 68 & 36.726 & 157 & 27.468 & 2.54 & 2.52 & 2.51 \\
\hline & Cherty mudstone & 05B007 & 68 & 36.812 & 157 & 27.409 & 2.53 & 2.51 & 2.49 \\
\hline & Cherty limestone & 05B280 & 68 & 36.904 & 157 & 27.318 & 2.49 & 2.44 & 2.41 \\
\hline & Wacke & $05 \mathrm{~B} 010$ & 68 & 36.366 & 157 & 28.835 & 2.71 & 2.67 & 2.64 \\
\hline Mean: & & & & & & & 2.58 & 2.54 & 2.53 \\
\hline
\end{tabular}

a down-dip (width) estimate of $180 \mathrm{~m}$ for the barite body. A slight increase in gravity values, without a corresponding rise in magnetic values at the southernmost end of each of the three profiles, is difficult to model without invoking barite (dense, but non-magnetic) or a previously unknown moderately dense, nonmagnetic rock type. The consistent northwestward regional increase in magnetic values is modeled by an increase in the volume of mafic sills within the Rim Butte unit of the Lisburne Group. These lithologies are exposed in the hills just northwest and uphill of the Longview deposit.

Profile 5 (figs. 8, 15) lies north of the Lakeview barite outcrops, and south of Longview, between the two sets of outcrops. Its gravity signature is equivocal, similar to that along profile 1 , but the data can be modeled as an irregular thin $(<10 \mathrm{~m})$ sheet of barite near the surface. No southeastern (down dip) limit to possible barite could be modeled in this profile due to a sharp and anomalous rise in observed gravity values at the last few stations to the southeast.

Profiles 6 and 7 (figs. 8,16,17) cross the northern and southern Lakeview barite outcrops respectively. These models indicate a gently southeastward dipping barite body with an irregular base and a maximum thickness of $24 \mathrm{~m}$. Profiles 6 and 7 provide a down-dip (width) estimate of 220 to $260 \mathrm{~m}$ for the Lakeview barite. The magnetic field along profile 6 (fig. 16) increases gradually southward, opposite to the regional gradient observed in profiles 2 through 5 . This southeastward rise, like that across profile 1 (fig. 11), cannot be accounted for by using the rock types and dips known from the area. The magnetic field along profile 7 can be modeled by the presence of a tabular, highly magnetic source (mafic sill) below and to the east of the barite.

The models along profiles perpendicular to strike of the barite approximate geologic cross sections (figs. 18, 19). Where the Rim Butte unit of the Lisburne Group, with local mafic sills, has been modeled below the Akmalik Chert, the contact between the two is always a low-angle thrust fault. Additional low-angle faults may bound some or all of the lithologies on these cross-sections but are not indicated.

Longview deposit geologic sections (fig. 18) suggest that the base of the barite is irregular, with significant changes in orientation and an overall southeastward dip of 10 to $25^{\circ}$. Estimated thickness of the barite varies from 15 to $24 \mathrm{~m}$. The shape of the basal contact is likely the result of folding of an original bedding surface during northward emplacement of the Akmalik Chert-bearing thrust sheets. An alternative hypothesis in which barite was originally deposited on a highly irregular sea-floor surface is unlikely given the deep-water and clasticpoor nature of the enclosing Akmalik Chert. Mafic sills intrude 
Table 3. Physical property values assigned to model blocks in profiles 1-8.

\begin{tabular}{|l|l|l|l|}
\hline \multicolumn{1}{|c|}{ Geologic unit } & \multicolumn{1}{|c|}{ Facies/ lithology } & $\begin{array}{c}\text { Specific gravity } \\
\text { (g/cc) }\end{array}$ & \multicolumn{1}{|c|}{$\begin{array}{c}\text { Magnetic } \\
\text { susceptibility (cgs) }\end{array}$} \\
\hline Lisburne Group & & & \\
\hline & Barite & 4.00 & 0 \\
\hline & Akmalik [black chert] & 2.52 & 0 \\
\hline & Rim Butte [limestone, dolostone, radiolarite] & 2.69 & 0.00001 \\
\hline Intrusions & Mafic sills [intrude Rim Butte only] & 2.93 & 0.0001 \\
\hline
\end{tabular}

the Rim Butte unit of the Lisburne Group in the thrust slice below the Longview deposit; their volume varies along strike and is greatest to the northwest of the deposit.

Geologic cross sections through the Lakeview deposit (fig. 19) also suggest an irregular, probably folded base to the barite, with a shallow overall dip of the body of 10 to $20^{\circ}$ to the southeast. Average thickness of modeled barite is thinner than at Longview, but the maximum thickness observed is also $24 \mathrm{~m}$. The number, thickness, and depth of mafic sills modeled in the fault slide of the Rim Butte below the Lakeview deposit, vary somewhat along strike but are consistent with regional exposures.

Models for profiles 8NE and 8SW (figs. 20, 21) have greater uncertainty than the others because they parallel the strike of the barite, and the assumption of near infinity in the third dimension is not met. However, the $23 / 4-\mathrm{D}$ features of the GM-SYS software allow the angle between the profile and bedrock strike to be specified and allow the third dimension to be approximated, rather than set to infinity. The models devel-

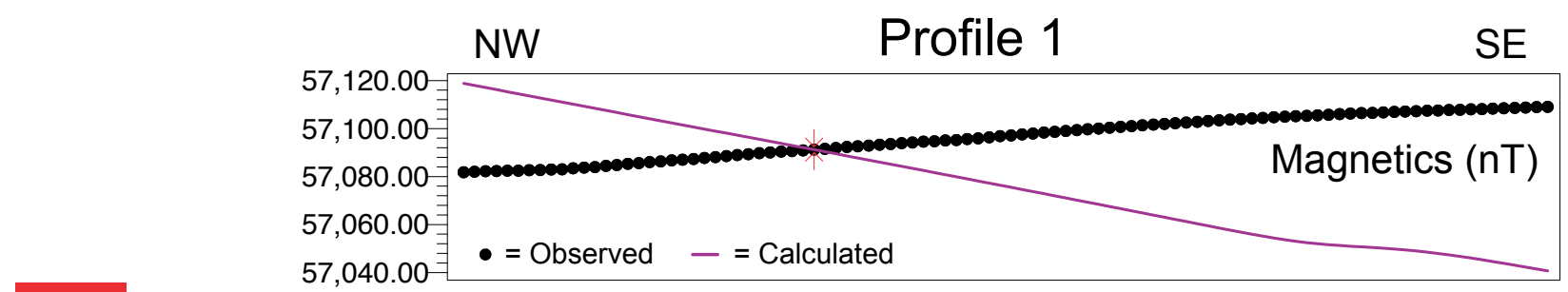

Mafic sills

Carbonate, shale etc.

Barite

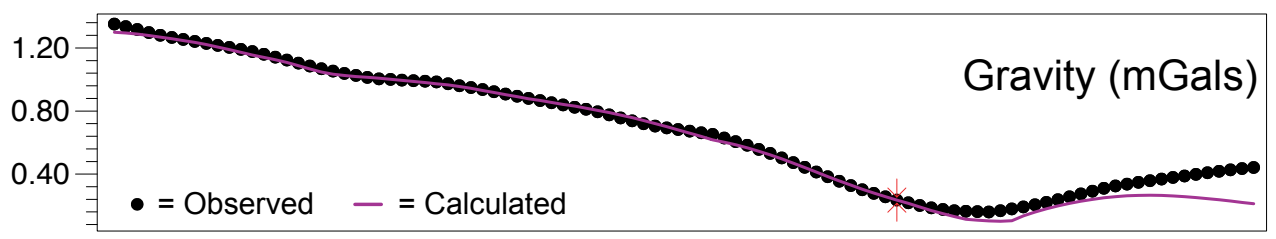

Akmalik Chert
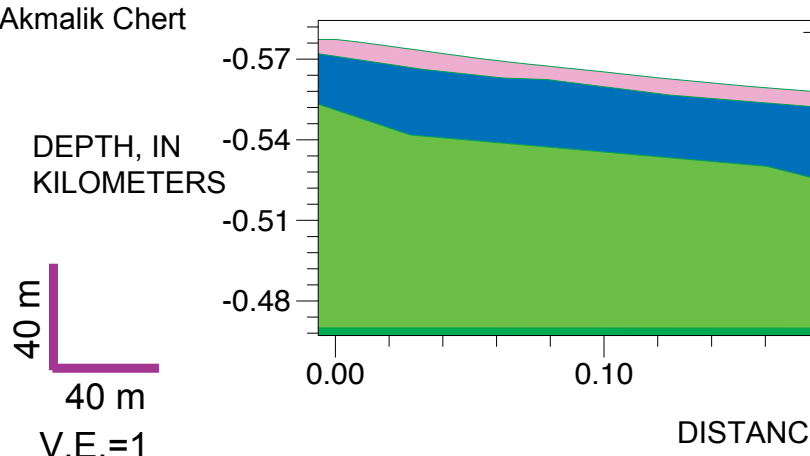
$-0.51$

$-0.48$ 0.00

DISTANCE, IN KILOMETERS

Figure 11. Potential field model along Profile 1, with no vertical exaggeration. The upper two panels show observed (black circles) and modeled (thin purple line) anomalies for magnetic (top) and gravity (center) fields, respectively. The third (bottom) panel shows the potential field model with individual bodies colored by geologic unit (pink = barite, blue = Akmalik Chert, red $=$ mafic sills; green = Rim Butte unit carbonate turbidites, shales, and all other lithologies). Densities and magnetic susceptibility assigned to each lithology are those indicated in Table 3. Wherever Rim Butte unit, with or without sills, are indicated below Akmalik Chert and(or) barite, the contact between the two is assumed to be structural; thrust faults are omitted for graphical clarity. 
oped for the along-strike profiles are internally consistent with the perpendicular ones (that is, thickness and depth of each source is matched at all intersections).

Although profiles $8 \mathrm{SW}$ and $8 \mathrm{NE}$ are neither contiguous nor exactly parallel, elevated gravity values between profiles 6 and 4 strongly suggest continuity of barite between the Longview and Lakeview outcrops and lend weight to the interpretation of barite along profile 5. A significant thickness $(>10 \mathrm{~m})$ of barite may occur immediately below tundra for a distance of at least $700 \mathrm{~m}$ north of the northernmost Lakeview outcrop. If this apparent continuity can be confirmed, use of two separate names for these deposits may not be warranted in the future.

Several relatively abrupt (tens of meters) changes in thickness of barite and magnetic rocks along strike occur and suggest the presence of relatively steep, cross faults with small (few meters) offset. An abrupt drop in gravity (fig. 20) indicates that barite terminates abruptly just north of profile 2 and suggests a steep northwest-oriented cross fault of less than 30 m offset. A sharp gravity low (fig. 21) suggests a $100 \mathrm{~m}$ gap in barite between the two Lakeview outcrops. Although gradual changes in mafic sill thickness over hundreds of meters are known from outcrop, more abrupt changes in magnetic properties (and modeled thickness of sills) suggest that similar steep cross structures may account for these variations.

\section{Discussion}

Although potential-field models are inherently nonunique, the series of internally consistent models presented here represent the best overall configuration of rock bodies that accounts for the observed gravity and magnetic data. These data constrain the size, shape, and orientation of the Lakeview and Longview barite bodies.

Because these models suggest continuity of barite in the subsurface (as much as $10 \mathrm{~m}$ thick) between the southernmost Longview and northernmost Lakeview exposures, the use of two separate deposit names may be unnecessary. Barite outcrops extend approximately $1.8 \mathrm{~km}$ along strike (NE-SW). A gap of approximately $100 \mathrm{~m}$ is indicated between the two outcrops of the Lakeview deposit, but elevated gravity values suggest barite continuity north of the Lakeview outcrops (fig. 21). The Longview deposit apparently terminates just north of profile 2 at a steep, probably northwest-oriented cross structure. Low gravity values along profile 1 suggest that barite of significant thickness $(\geq 3 \mathrm{~m})$ is unlikely to occur there or further to the north. Other northwest-trending structures, which show small (few meters) apparent offset (figs., 20, 21 ), are interpreted to occur north of the Longview outcrops (north of profile 2), between Longview and Lakeview (just south of profile 4), and possibly between the two modeled
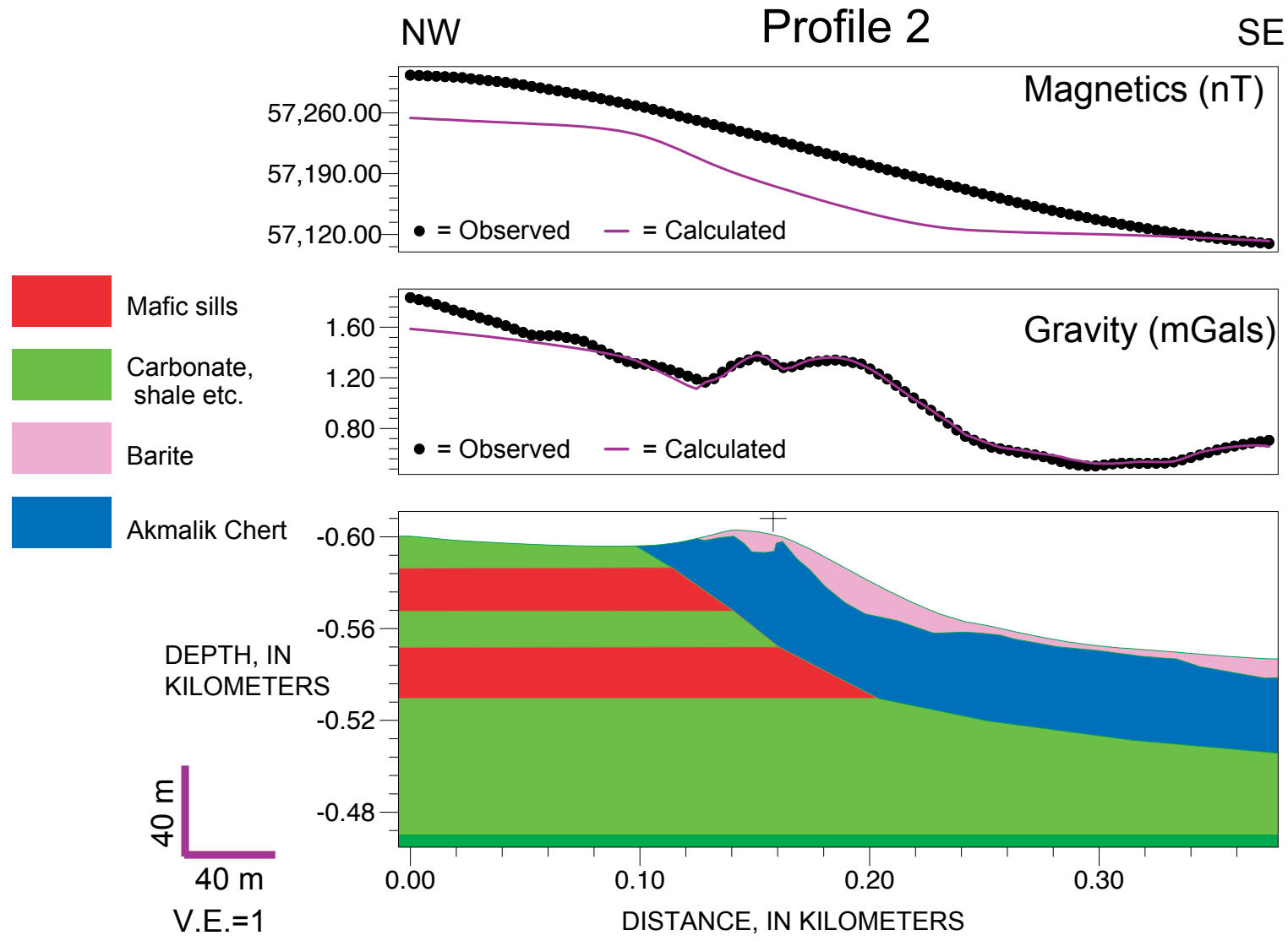

Figure 12. Potential field model along Profile 2. Panel and unit descriptions are the same as in figure 11. 


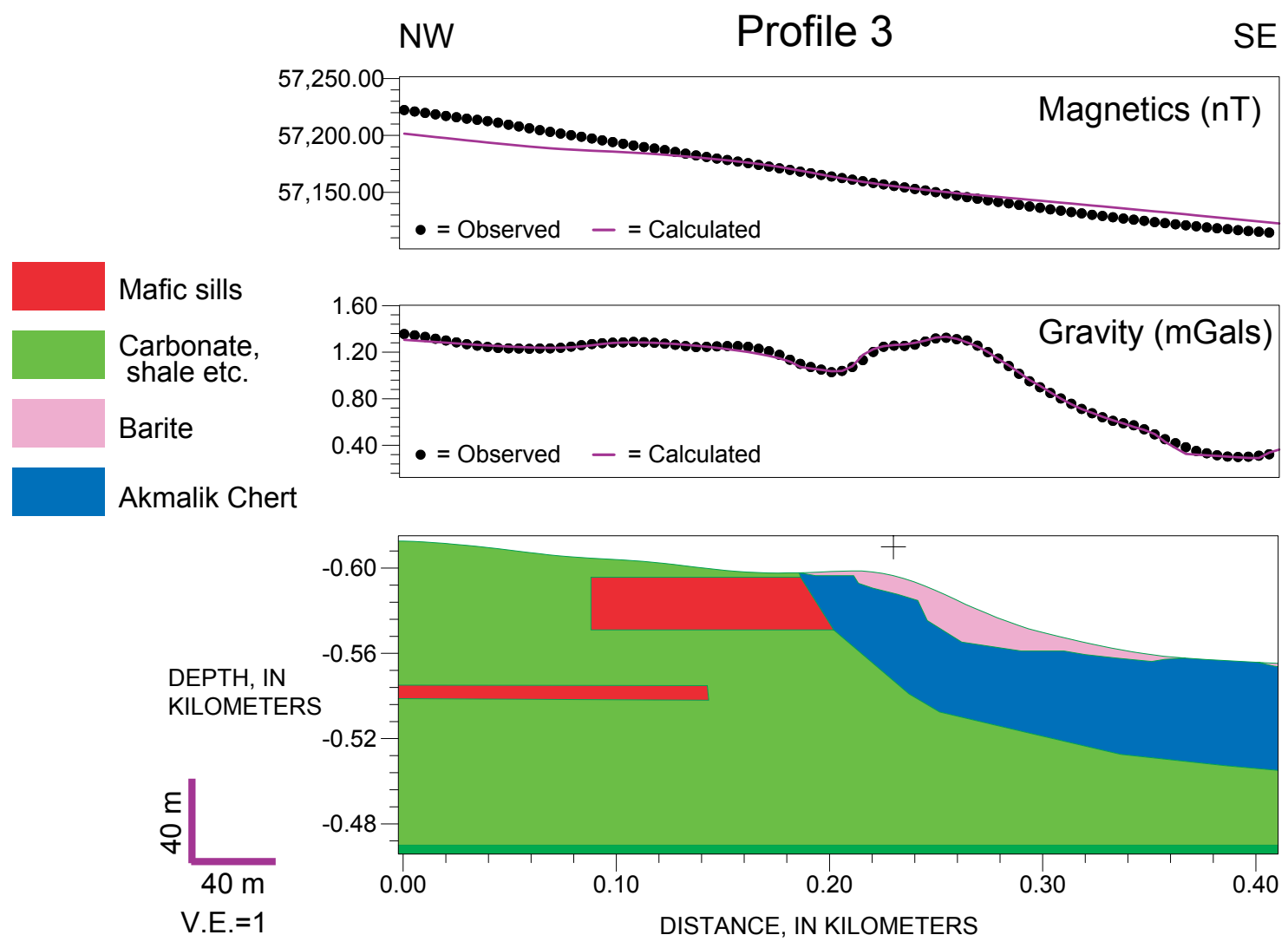

Figure 13. Potential field model along Profile 3. Panel and unit descriptions are the same as in figure 11.

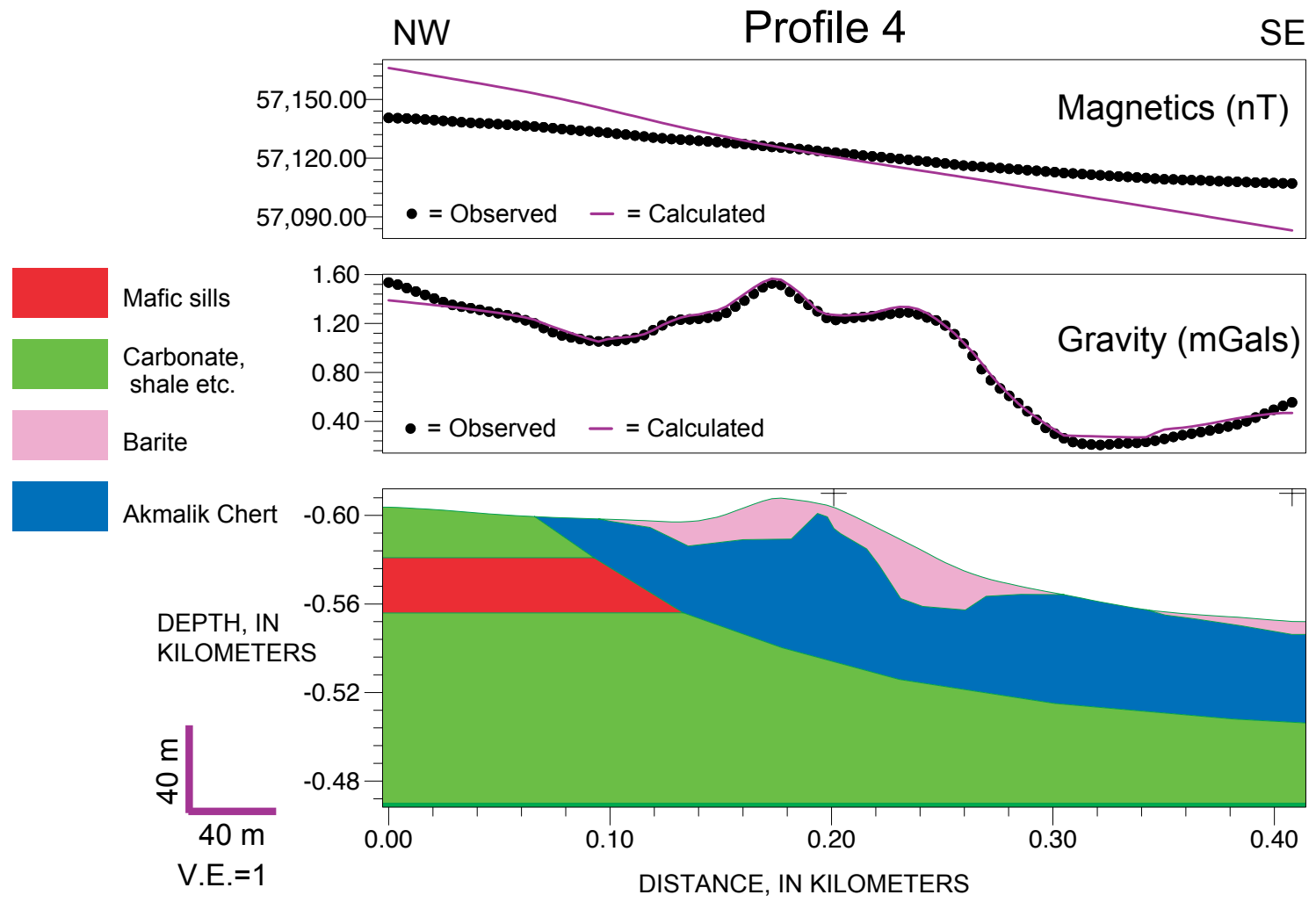

Figure 14. Potential field model along Profile 4. Panel and unit descriptions are the same as in figure 11. 

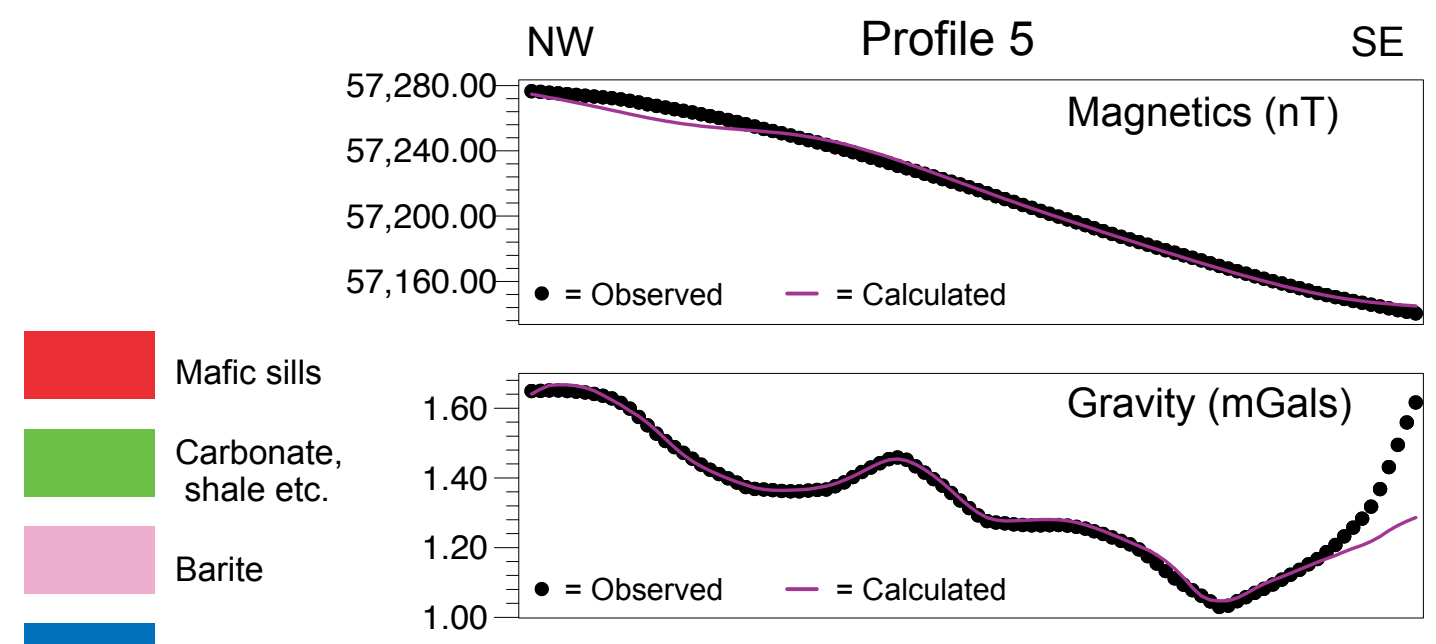

Akmalik Chert

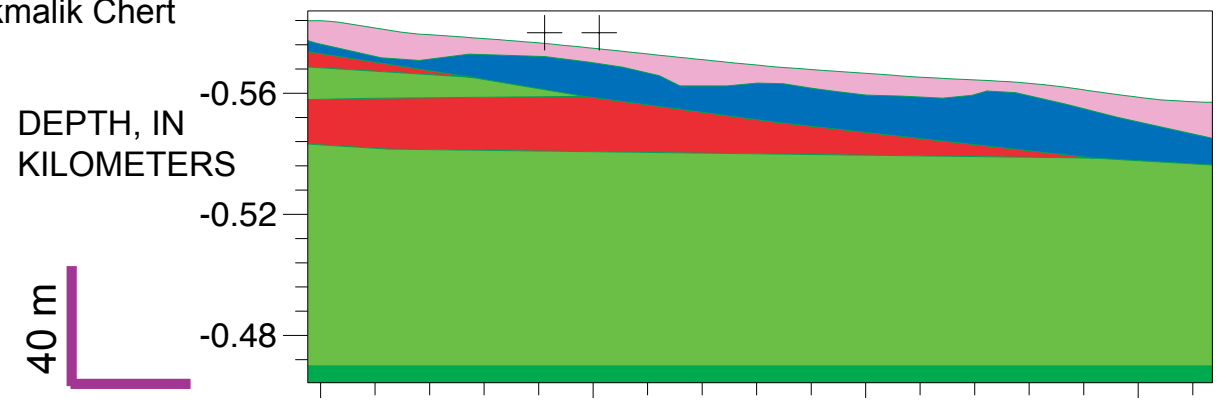

Figure 15. Potential field model along Profile 5. Panel and unit descriptions are the same as in figure 11.
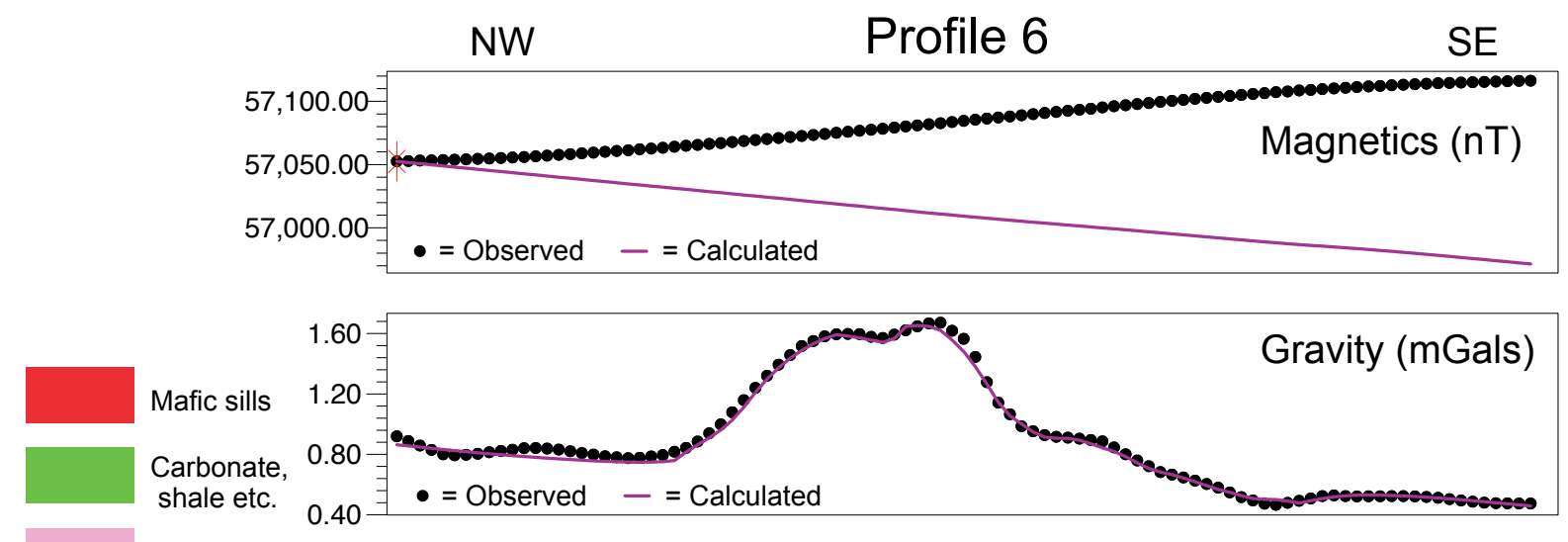

Barite

Akmalik Chert

DEPTH, IN ${ }^{-0.56}$

KILOMETERS

$-0.52$

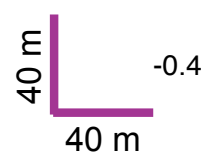

$-0.48$

$40 \mathrm{~m}$
$V . E .=1$

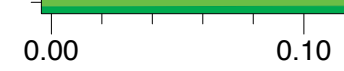

0.10

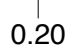

DISTANCE, IN KILOMETERS

Figure 16. Potential field model along Profile 6. Panel and unit descriptions are the same as figure 11. 
segments of the Lakeview barite (just south of profile 6). A lack of barite outcrops and a drop in gravity values $20 \mathrm{~m}$ southwest of profile 7 suggest an abrupt southern end to the Lakeview deposit. However, the Stack prospect (Kelley and others, 1993, Kurtak and others, 1995) just west of Lake 573 (figs. 3, 22) includes three low-lying outcrops of eastto northeast-striking barite. Additional barite may occur in the unexplored covered interval ( $\sim 800 \mathrm{~m}$ in extent) between the southernmost Lakeview outcrop (fig. 22) and the Stack, which would extend the possible strike length of barite to $>2.6 \mathrm{~km}$ overall.

Maximum thickness of the Longview barite deposit is 15 to $24 \mathrm{~m}$; its irregular (nonplanar) base suggests folding related to northward-directed Cretaceous thrusting. Lakeview is 9 to $24 \mathrm{~m}$ thick at its maximum; its base is also irregular, but not as discordant as that of Longview. Shallow dips $\left(10\right.$ to $\left.25^{\circ} \mathrm{SE}\right)$ of the barite, indicated by the models, are less than previous estimates based on outcrop apparent dips. True width of the bodies (the least certain dimension) is a minimum of $110 \mathrm{~m}$ for Longview; the three cross-strike models suggest a width of 160 to $200 \mathrm{~m}$. Width of the Lakeview barite is a minimum of $120 \mathrm{~m}$; models along profiles 6 and 7 suggest a range of 220 to $260 \mathrm{~m}$. However, the regional gravity data are too widely spaced for accurate res- olution of the down-dip (southeastern) limits of the barite bodies, so this dimension is less certain than the thickness and strike lengths.

Simple volume calculations from these dimensions (length $\mathrm{x}$ width $\mathrm{x}$ thickness $\mathrm{x}$ density), made by using a mean specific gravity of $4.08 \mathrm{~g} / \mathrm{cc}$ (table 2 ) and conservative values of width, thickness, and strike length, suggest that a minimum of 4.5 million metric tons of barite occurs at the combined Lakeview and Longview deposits (table 4). The maximum possible calculated tonnage $(38.6 \mathrm{Mt})$ would require continuity of barite thicknesses across wide areas of untested strike length. Estimated volumes made by using midrange values for width and thickness, and conservative strike lengths are $7.4 \mathrm{Mt}$ of barite at Longview $(20 \mathrm{~m} \times 180$ $\mathrm{m} \times 500 \mathrm{~m})$ and $11.0 \mathrm{Mt}$ of barite at Lakeview (16 m x 240 $\mathrm{m} \times 700 \mathrm{~m}$ ).

The potential for any of the barite deposits of Cutaway Basin area to be economically minable is uncertain and dependent on land status and policy decisions within NPRA, as well as on geologic and engineering conditions. Although sampling to date is inadequate to fully characterize the quality of the resource, the barite bodies sampled so far are high grade, with high specific gravities and low amounts of impurities, such as silica, carbonate, and trace

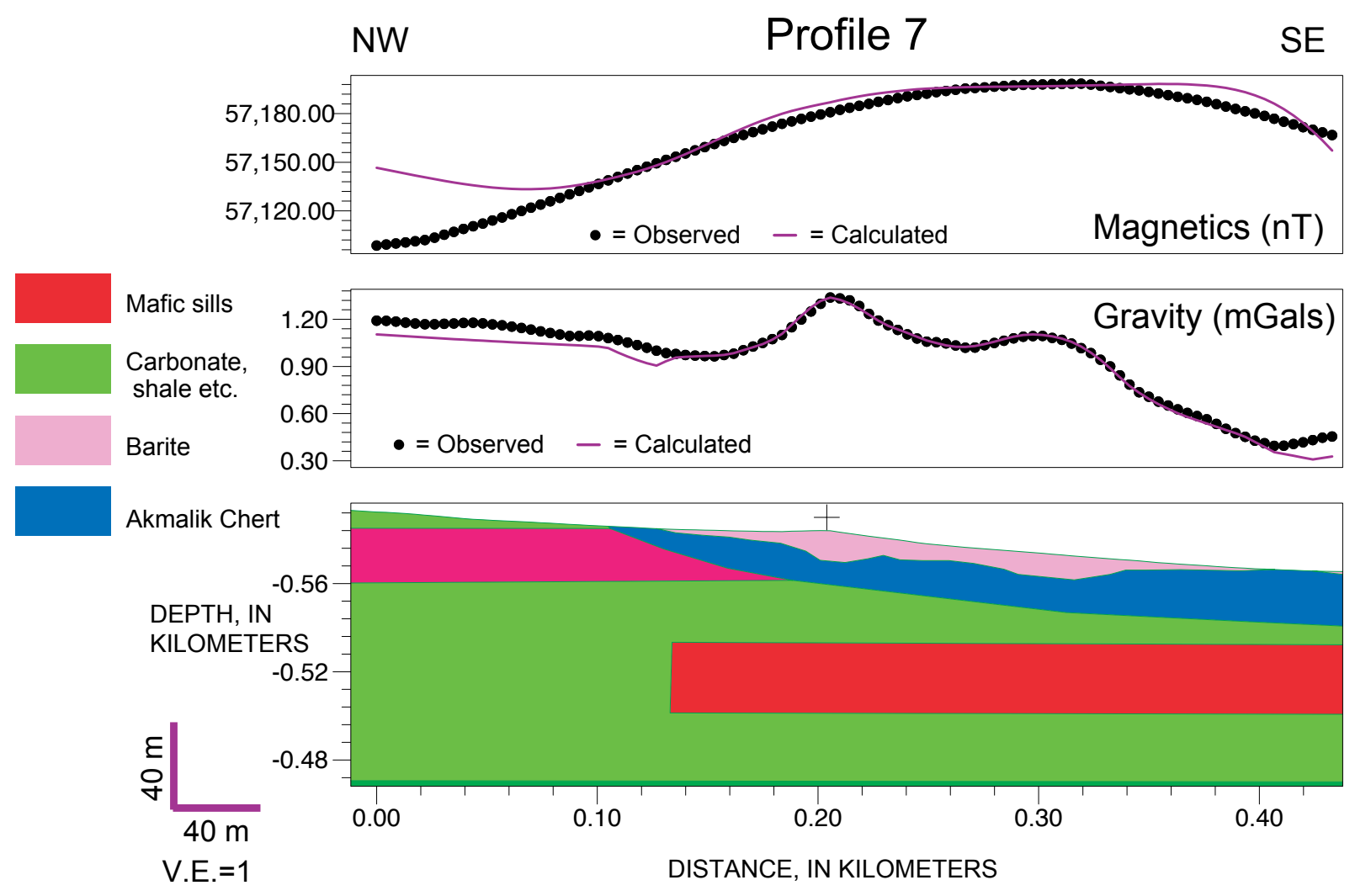

Figure 17. Potential field model along Profile 7. Panel and unit descriptions are the same as figure 11. 


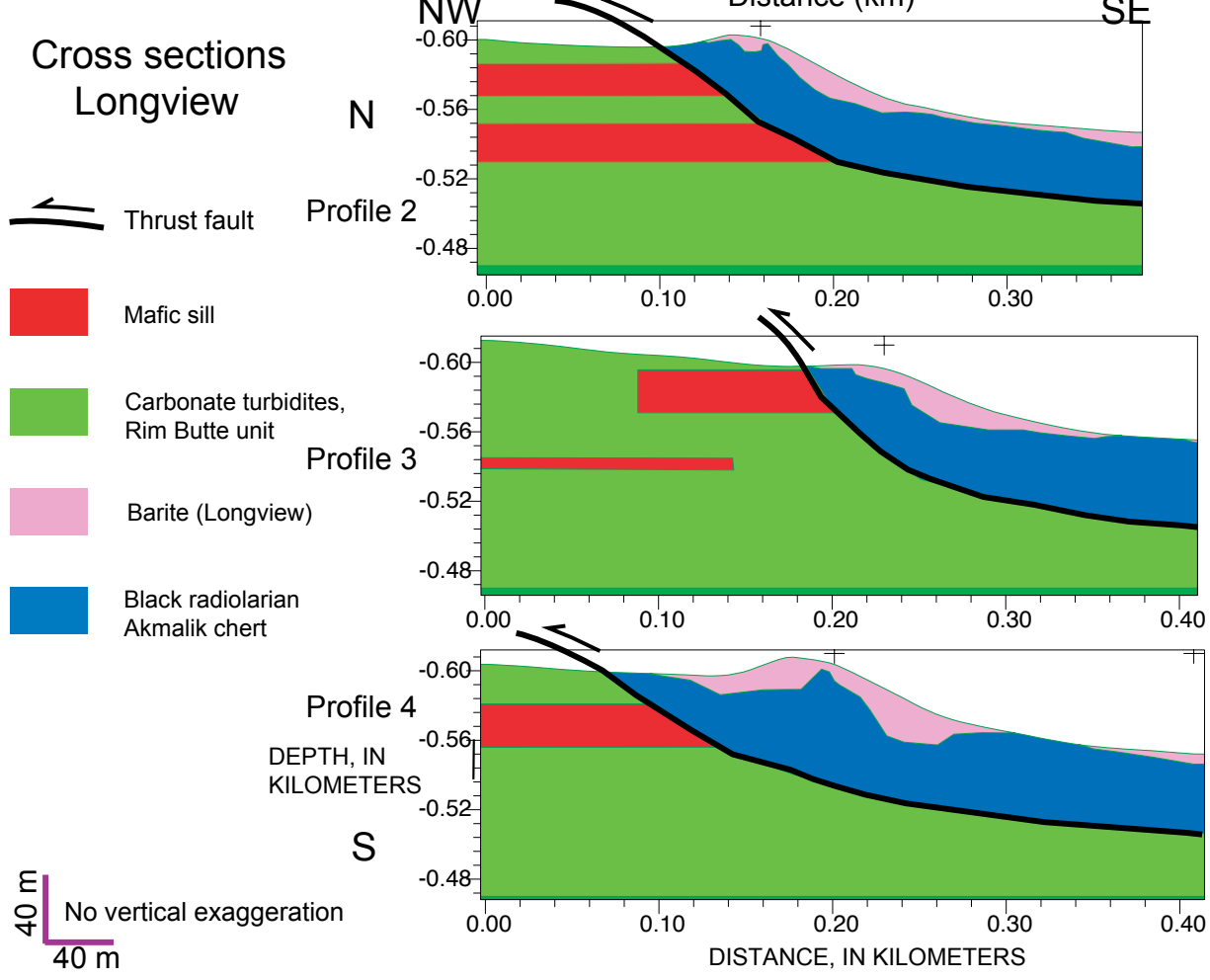

Figure 18. Geologic cross sections through the Longview barite deposit.
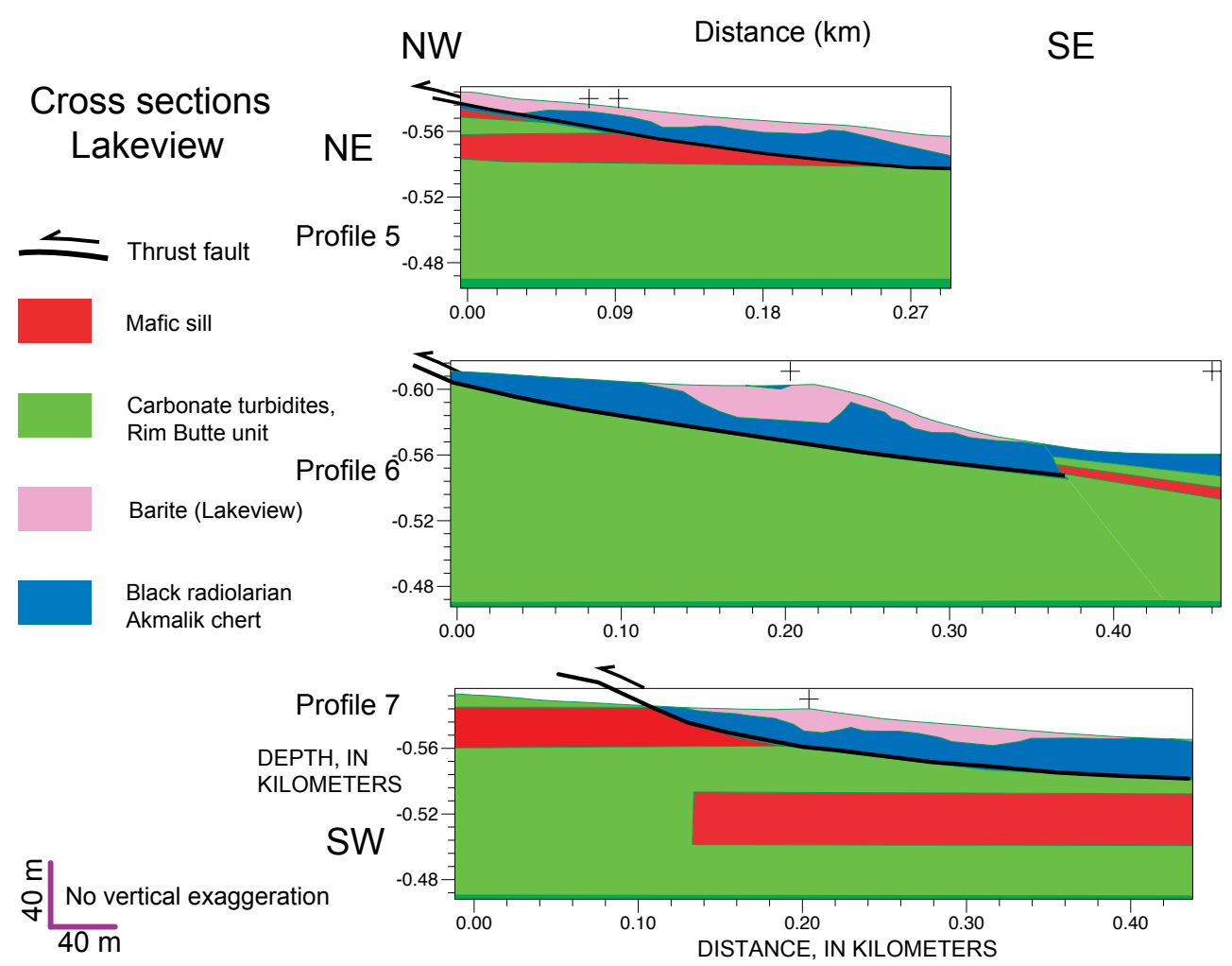

Figure 19. Geologic cross sections through the Lakeview deposit. 

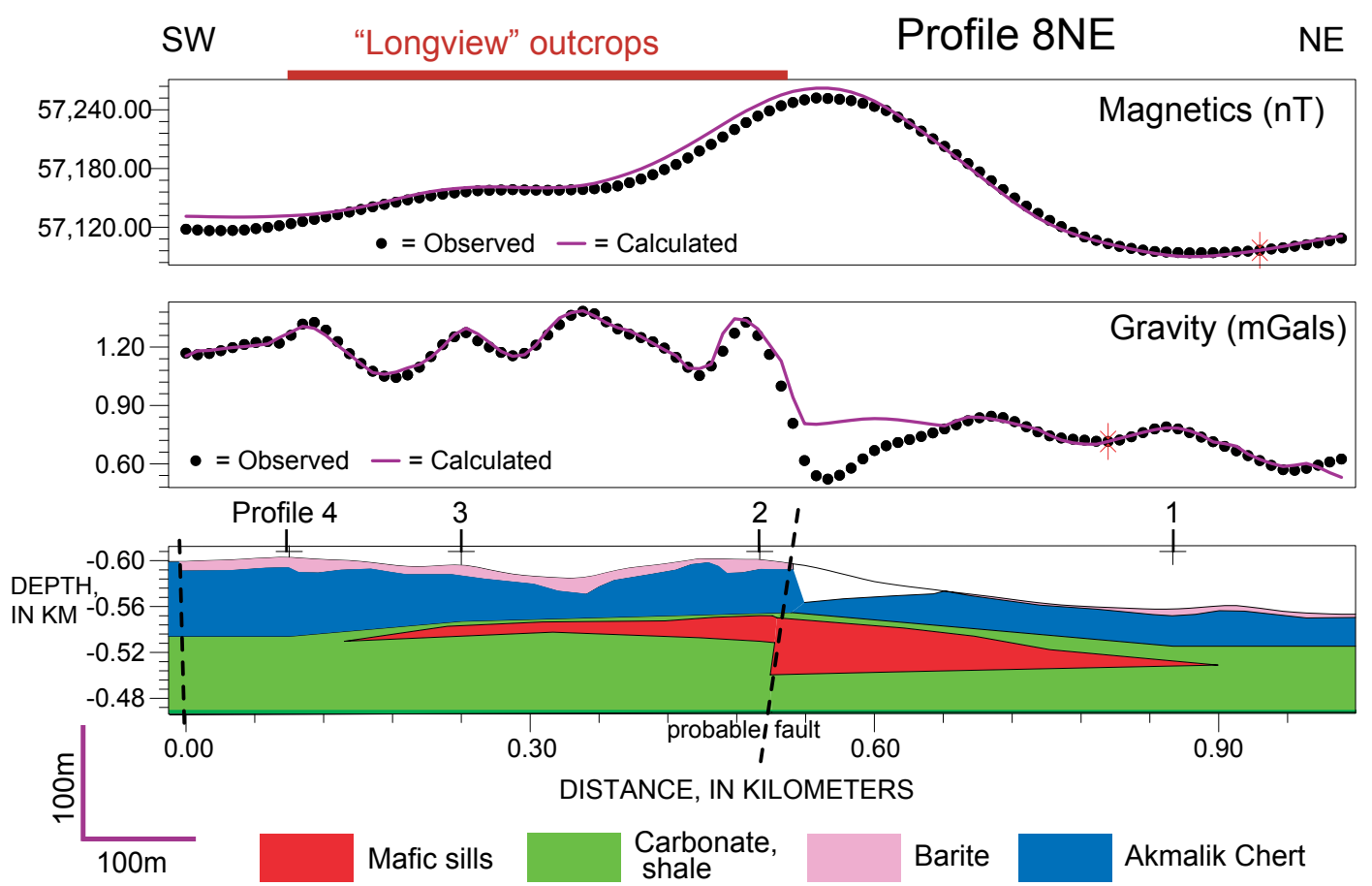

Figure 20. Potential field model along Profile 8NE. Panel and unit descriptions are the same as figure 11. Extent of barite outcrops (red bars) and locations of intersecting profiles (numbered) are indicated. The contact between the Akmalik chert and Rim Butte unit of the Lisburne Group is everywhere assumed to be structural; thrust faults are omitted for graphical clarity.
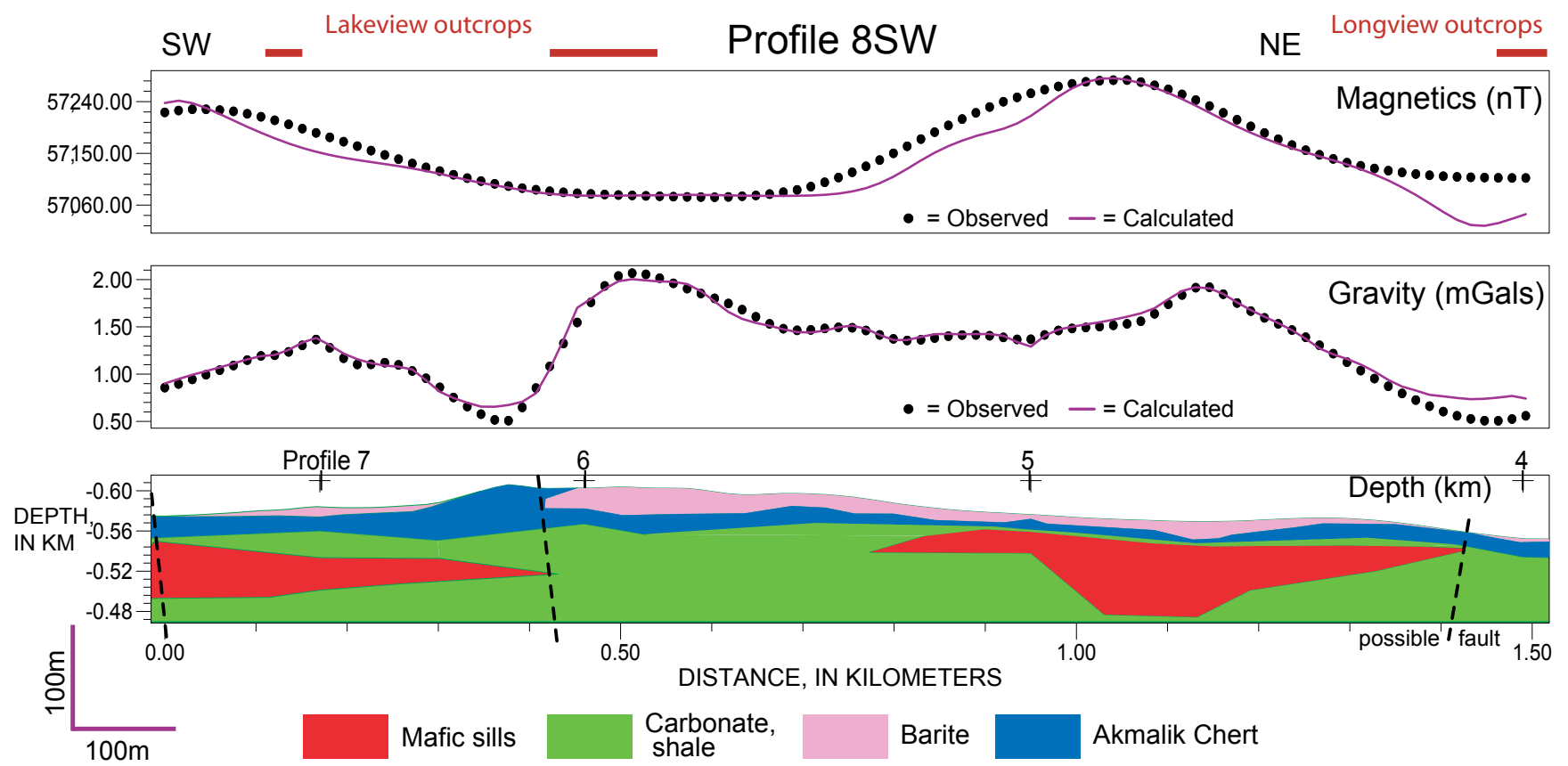

Figure 21. Potential field model along Profile 8SW. Panel and unit descriptions are the same as figure 11. Extent of barite outcrops (red bars) and locations of intersecting profiles (numbered) are indicated. The contact between the Akmalik chert and Rim Butte unit of the Lisburne Group is everywhere assumed to be structural; thrust faults are omitted for graphical clarity 
metals. Very detailed geologic mapping could indicate the full extent of suitable host rocks and evaluate possible continuity of barite between Stack, Lakeview, and other nearby occurrences. Heavy mineral concentrate samples from streams in the area and soil sampling may indicate additional barite bodies or extensions to known deposits. Additional gravity data along wide-spaced regional lines, as well as across known occurrences, would significantly improve volume estimates. Trace element analyses and physical property measurements of bulk barite samples are required to fully evaluate grades, and trenching or drilling of each body will be required to fully define available tonnages.

\section{Acknowledgments}

We thank Joe Kurtak (BLM) and Karen Kelley (USGS) for providing logistical support to R. Morin for the 2005 field study. Julie Dumoulin and Darcy McPhee provided helpful reviews.

\section{References Cited}

Barnes, D.F., Mayfield, C.F., Morin, R.L., and Brynn, S., 1982, Gravity measurements useful in the preliminary evaluation of the Nimiuktuk barite deposit, Alaska: Economic Geology, v. 77, p. 185-198.

Beaty, C.J., Mewyer, J.F. Jr., Decker, P.L., Pritchard, M.E., and Krouskop, D.L., 2006, Gravity and magnetic data: State of Alaska, Department of Natural Resources, Division of Oil and Gas, North Slope Resource Series, Plate 4-Gravity and magnetic data availability for the North Slope of Alaska [http://www.dog.dnr.state.ak.us/oil/products/maps/ northslope/northslope.htm, last accessed January 23, 2009].

Blakely, R.J., 1995, Potential theory in gravity and magnetic applications: Cambridge, Cambridge University Press, $441 \mathrm{p}$.

Blakely, R.J., and Connard, G.G., 1989, Crustal studies using magnetic data, in Pakiser, L.C., and Mooney, W.D., eds., Geophysical framework of the continental United States: Geological Society of America Memoir, v. 172, p. 45-60.

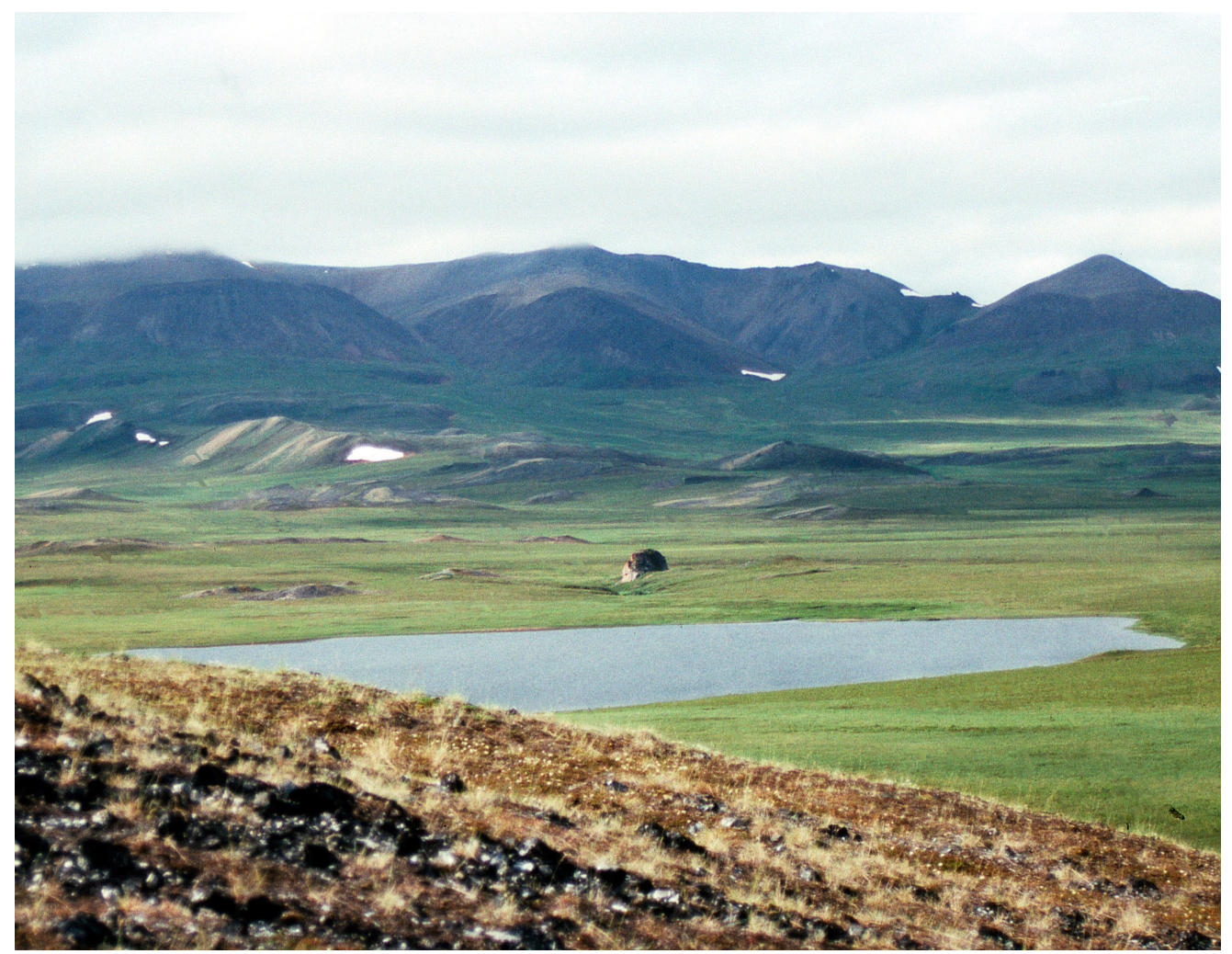

Figure 22. View southwestward from the southern outcrop of the Lakeview deposit across Lake 573 toward the Stack barite occurrence. The white and dark knob in the center midground is an outcrop of limestone informally named the Stack. Barite occurs in three low rubble and outcrop mounds a few meters to tens of meters north (to the right) of the limestone outcrop. 
Table 4. Estimates of size and shape of Longview/Lakeview barite bodies.

\begin{tabular}{|c|l|l|l|l|l|}
\hline & & Thickness & Strike length & \multicolumn{1}{c|}{ Width } & \multicolumn{1}{c|}{ Volume } \\
\hline Longview & $\begin{array}{l}\text { Kelley and } \\
\text { others, } 1993\end{array}$ & $30 \mathrm{~m}$ & $690 \mathrm{~m}$ & $345 \mathrm{~m}$ & $29.49 \mathrm{Mt}$ \\
\hline & This study & $15-24 \mathrm{~m}$ & $450-540 \mathrm{~m}$ & $\begin{array}{l}\text { Minimum 110 m } \\
\text { Modeled range: } 160-200 \mathrm{~m}\end{array}$ & $\begin{array}{l}\text { Range 3.0-10.6 Mt } \\
\text { Mid-range values: } 7.4 \mathrm{Mt}\end{array}$ \\
\hline Lakeview & $\begin{array}{l}\text { Kelley and } \\
\text { others, } 1993\end{array}$ & $10 \mathrm{~m}$ & $425 \mathrm{~m}$ & $210 \mathrm{~m}$ & $3.77 \mathrm{Mt}$ \\
\hline & This study & $9-24 \mathrm{~m}$ & $\begin{array}{l}350-1,100 \mathrm{~m} \\
\text { (two segments) }\end{array}$ & $\begin{array}{l}\text { Minimum } 120 \mathrm{~m} \\
\text { Modeled range 220-260 m }\end{array}$ & $\begin{array}{l}\text { Range 1.5-28.0 Mt } \\
\text { Mid-range values: } 11.0 \mathrm{Mt}\end{array}$ \\
\hline Total & $\begin{array}{l}\text { Kelley and } \\
\text { others, } 1993\end{array}$ & & $1.6 \mathrm{~km}$ & & $33.3 \mathrm{Mt}$ \\
\hline & \begin{tabular}{l} 
This study \\
\hline
\end{tabular} & & $1.8 \mathrm{~km}$ & & $\begin{array}{l}\text { Range: } 4.5-38.6 \mathrm{Mt} . \\
\text { Mid-range values: } 18.4 \mathrm{Mt}\end{array}$ \\
\hline
\end{tabular}

Blome, C.D., Reed, K.M., and Harris, A.G., 1998, Radiolarian and conodont biostratigraphy of the type section of the Akmalik Chert (Mississippian), Brooks Range, Alaska, in Gray, J.E., and Riehle, J.R., eds., Geologic Studies in Alaska by the U.S. Geological Survey, 1996: U.S. Geological Survey Professional Paper 1595, p. 51-69.

Burns, L.E., U.S. Bureau of Land Management, Fugro Airborne Surveys, and Stevens Exploration Management Corp., 2006, Line, grid, and vector data and plot files for the airborne geophysical survey data of parts of the southern National Petroleum Reserve-Alaska, Northwest Alaska: Alaska Division of Geological and Geophysical Surveys, Geophysical Report 20061, 3 disks [http://www.dggs.dnr.state.ak.us/pubs/ pubs? reqtype $=$ citation $\& I D=14501$, last accessed January 23, 2009].

Cordell, L., and McCafferty, A.E., 1989, A terracing operator for physical property mapping with potentialfield data: Geophysics, v. 54, p. 621-634.

Dover, J.H., Tailleur, I.L., and Dumoulin, J.A., 2004, Geologic and fossil locality maps of the west-central part of the Howard Pass quadrangle and part of the adjacent Misheguk Mountain quadrangle, Western Brooks Range, Alaska: U.S. Geological Survey Miscellaneous Field Studies Map MF-2413, 76 p, 2 sheets, scale 1:100,000.

Dobrin, M.B., and Savit, C.H., 1988, Introduction to geophysical prospecting (4th ed.): New York, McGrawHill, 867 p.

Dumoulin, J.A., Harris, A.G., and Schmidt, J.M., 1993, Deep-water lithofacies and conodont faunas of the Lisburne Group, west-central Brooks Range, Alaska in Dusel-Bacon, Cynthia, and Till, A.B., eds., Geologic studies in Alaska 1992: U.S. Geological Survey Bulletin 2068, p. 12-30.

Dumoulin, J.A., Harris, A.G., and Schmidt, J.M., 1994, Deep-water facies of the Lisburne Group, westcentral Brooks Range, Alaska in Thurston, D.K., and Fujita, Kazuya, eds., 1992 Proceedings, International
Conference on Arctic Margins, Anchorage, Alaska, September, 1992: Anchorage, Minerals Management Service, Outer Continental Shelf Study MMS 94-0040, p. 77-82.

Dumoulin, J.A., Harris, A.G., Blome, C.D., and Young, L.E., 2004, Depositional settings, correlation, and age of Carboniferous rocks in the western Brooks Range: Economic Geology, v. 99, no. 7, p. 1355-1384.

Glen, J.M.G., Schmidt, J.M., and Morin, R.L., 2006, Preliminary 2D potential-field models of the Longview and Lakeview deposits, southern National Petroleum Reserve, Alaska (NPRA), [abs.]: Mining-Energizing Alaska's Mineral Industry: Abstracts from Alaska Miner's Association Annual Meeting, Nov. 6-11, 2006, Anchorage, Alaska, p. 11-12.

Grauch, V.J.S., and Cordell, L., 1987, Limitations of determining density or magnetic boundaries from the horizontal gradient of gravity or pseudogravity data: Geophysics, v. 52, p. 118-121.

Gryc, George, ed., 1988, Geology and exploration of the National Petroleum Reserve in Alaska, 1974 to 1982: U.S. Geological Survey Professional Paper 1399, 940 p.

Harben, P.W., and Kuzvart, M., 1996, Industrial minerals- a global geology: London, Industrial Minerals Information Ltd., Metal Bulletin, PLC, 462 p.

Kelley, J.S., Tailleur, I.M., Morin, R.L., Reed, K.M., Harris, A.G., Schmidt, J.M., Brown, F.M., and Kurtak, J.M., 1993, Barite deposits in the Howard Pass quadrangle and possible relations to barite elsewhere in the northwestern Brooks Range: U.S. Geological Survey Open-File Report 93- 215, 13 p., 9 plates, scale 1:63,360.

Kurtak, J.M., Meyer, M.P., Hicks, R.W., Werdon, M.B., and Mull, C.G., 1995, Mineral investigations in the Colville Mining District and southern National Petroleum Reserve in Alaska: U.S. Bureau of Mines Open-File Report 8-95, $217 \mathrm{p}$.

Mayfield, C.F., Curtis, S.M., Ellersieck, I.F., and Tailleur, I.L, 1979a, The Ginny Creek zinc-lead-silver and Nimiuktuk barite deposits, northwestern Brooks Range, Alaska: U.S. 
Geological Survey Circular 804-B, p. B11-B13.

Mayfield, C.F., Curtis, S.M., Ellersieck, I.F., and Tailleur, I.L, 1979b, Reconnaissance geology of the Ginny Creek zinc-lead-silver and Nimiuktuk barite deposits, northwestern Brooks Range, Alaska: U.S. Geological Survey Open File Report 79-1092, 20 p.

Miller, M.M., 2008, Barite, in Mineral commodity summaries 2008: U.S. Geological Survey, p. 30-31 [http://minerals.usgs.gov/minerals/pubs/mcs/, last accessed January 23, 2009].

Moore, T.E., Wallace, W.K., Bird, K.J., Karl, S.M., Mull, C.G., and Dillon, J.T., 1994, Geology of northern Alaska, in Plafker, George, and Berg, H.C., eds., The geology of Alaska, v. G-1 of The Geology of North America: Boulder, Colo., Geological Society of America, p. 49-140.

Morin, R.L., 1997, Gravity models of Abby Creek and Bion barite deposits, Howard Pass quadrangle, Northwestern Brooks Range, Alaska: U.S. Geological Survey OpenFile Report 97-704.

Mull, C.G., Crowder, R.K., Adams, K.E., Siok, J.P., Bodnar, D.A., Harris, E.E., Alexander, R.A., and Solie, D.N., 1987, Stratigraphy and structural setting of the Picnic Creek allochthon, Killik River quadrangle, central Brooks Range, Alaska-A summary, in Tailleur, I.L., and Weimer, Paul, eds., Alaskan North Slope geology, v. 2: Bakersfield, Calif., Society of Economic Paleontologists and Mineralogists, Pacific Section, p. 649-661.

Mull, C.G., Tailleur, I.L., Mayfield, C.F., and Ellersieck, I.F., 1982, New upper Paleozoic and lower Mesozoic stratigraphic units, central and western Brooks Range, Alaska: American Association of Petroleum Geologists Bulletin, v. 66, no. 3, p. 348-362.

Murchey, B.L., Jones, D.L., Holdsworth, B.K., and Wardlaw, B.R., 1988, Distribution patterns of facies, radiolarians, and conodonts in the Mississippian to Jurassic siliceous rocks of the northern Brooks Range, Alaska, in Gryc, George, ed., U.S. Geological Survey Professional Paper 1399, p. 697-724.
Nazarova, K., and Glen, J.M.G., 2004, Integration of NASA/GSFC and USGS Rock Magnetic Databases: Eos (American Geophysical Union Transactions), v. 85, no. 17, abstract GP21A-04.

Saltus, R.W., and Simmons, G.C., 1997, Composite and merged aeromagnetic data for Alaska; a web site for distribution of gridded data and plot files, U.S. Geological Survey, Open-File Report 97-0520, 15 p.

Saltus, R.W., Hudson, T.L., and Phillips, J.D., 2001, Basement geophysical interpretation of the National Petroleum Reserve Alaska (NPRA), northern Alaska-Part I, Overview: U.S. Geological Survey Open File Report 01-0476 http://pubs.usgs.gov/of/2001/ofr-01-0476/ (last accessed January 23, 2009).

Saltus, R.W., Hudson, T.L., Phillips, J.D., Kulander, C., Dumoulin, J.A., and Potter, C., 2002, Basement geology of the National Petroleum Reserve Alaska (NPRA), northern Alaska: U.S. Geological Survey Open File Report 01-0127, 14 p http://pubs.usgs.gov/of/2002/ofr02-0127/ (last accessed January 23, 2009).

Schmidt, J.M., 1997, Shale-hosted Zn-Pb-Ag and barite deposits of Alaska, in Goldfarb, R.J., and Miller, L., eds., Mineral deposits of Alaska: Economic Geology Monograph 9, p. 35-65.

Spicer, R.A., and Thomas, B.A., 1987, A Mississippian Alaska-Siberia connection-Evidence from plant megafossils, in Tailleur, I.L., and Weimer, Paul, eds., Alaskan North Slope geology, v. 2: Bakersfield, Calif., Society of Economic Paleontologists and Mineralogists, Pacific Section, p. 355 - 358.

Tailleur, I.L., Kent, B.H., Jr., and Reiser, H.N., 1966, Outcrop/geologic maps of the Nuka-Etivluk region, northern Alaska: U.S. Geological Survey Open File Report, 7 sheets, scale 1:63,360.

Talwani, M., Worzel, J.L., and Landisman, M.G., 1959, Rapid gravity computations for two-dimensional bodies with application to the Mendocino submarine fracture zone [Pacific Ocean]: Journal of Geophysical Research, v. 64 , no. 1, p. $49-59$. 


\section{Appendix - Principal facts of gravity data from Lakeview and Longview}

All data were measured with a LaCoste and Romberg G-model gravimeter modified to average and record readings. Locations and elevation measurements were made by using a Trimble 4400 GPS instrument with a precision of $\sim 1.5 \mathrm{~cm}$; many stations, however, were on tundra above an uncertain ground surface. 
Appendix. Principal facts of gravity data from Lakeview and Longview.

[Data collected by R. Morin, 2005; FAA, free air anomaly; SBA, Simple Bouguer anomaly; Inner TC, terrain correction from station to $580 \mathrm{~m}$; Outer TC, terrain correction from $580 \mathrm{~m}$ to $166.7 \mathrm{~km}$; CBA, complete Bouguer anomaly; ISO, isostatic anomaly]

\begin{tabular}{|c|c|c|c|c|c|c|c|c|c|c|c|c|}
\hline \multirow[t]{2}{*}{ Station ID } & \multicolumn{2}{|c|}{ Latitude } & \multicolumn{2}{|c|}{ Longitude } & \multirow{2}{*}{$\begin{array}{l}\text { Elev } \\
\text { (ft) }\end{array}$} & \multirow{2}{*}{$\begin{array}{c}\text { Observed } \\
\text { Gravity }\end{array}$} & \multirow{2}{*}{$\begin{array}{c}\text { FAA } \\
\text { (mGal) }\end{array}$} & \multirow{2}{*}{$\begin{array}{c}\text { SBA } \\
\text { (mGal) }\end{array}$} & \multirow{2}{*}{$\begin{array}{c}\text { Inner } \\
\text { TC }\end{array}$} & \multirow{2}{*}{$\begin{array}{c}\text { Outer } \\
\text { TC }\end{array}$} & \multirow{2}{*}{$\begin{array}{c}\text { CBA } \\
\text { (mGal) }\end{array}$} & \multirow{2}{*}{$\begin{array}{c}\text { ISO } \\
\text { (mGal) }\end{array}$} \\
\hline & Deg & Minute & Deg & Minute & & & & & & & & \\
\hline 05B0022 & 68 & 36.909 & 157 & 27.265 & 1964.3 & 982355.6 & 14.89 & -52.11 & 0.24 & 0.74 & -51.13 & 0.97 \\
\hline $05 \mathrm{~B} 0023$ & 68 & 36.913 & 157 & 27.278 & 1960.5 & 982355.74 & 14.67 & -52.2 & 0.33 & 0.83 & $\begin{array}{l}-51.04 \\
\end{array}$ & 1.06 \\
\hline $05 \mathrm{~B} 0024$ & 68 & 36.918 & 157 & 27.293 & 1960.6 & 982355.75 & 14.68 & -52.19 & 0.35 & 0.85 & -50.99 & 1.11 \\
\hline $05 \mathrm{~B} 0025$ & 68 & 36.921 & 157 & 27.306 & 1960.1 & 982355.85 & 14.73 & -52.12 & 0.37 & 0.87 & -50.88 & 1.22 \\
\hline $05 \mathrm{~B} 0026$ & 68 & 36.925 & 157 & 27.321 & 1962.1 & 982355.73 & 14.79 & -52.13 & 0.4 & 0.9 & -50.83 & 1.26 \\
\hline $05 \mathrm{~B} 0027$ & 68 & 36.931 & 157 & 27.349 & 1970.1 & 982355.19 & 15 & -52.19 & 0.42 & 0.92 & -50.85 & 1.24 \\
\hline 05B0028 & 68 & 36.938 & 157 & 27.374 & 1978.9 & 982354.68 & 15.31 & -52.18 & 0.44 & 0.94 & -50.8 & 1.29 \\
\hline $05 \mathrm{~B} 0029$ & 68 & 36.945 & 157 & 27.402 & 1983.1 & 982354.43 & 15.44 & -52.19 & 0.45 & 0.95 & -50.79 & 1.28 \\
\hline $05 \mathrm{~B} 0030$ & 68 & 36.951 & 157 & 27.426 & 1987 & 982354.27 & 15.65 & -52.12 & 0.39 & 0.89 & -50.84 & 1.23 \\
\hline 05B0031 & 68 & 36.97 & 157 & 27.453 & 2001.7 & 982353.39 & 16.14 & -52.14 & 0.41 & 0.91 & -50.82 & 1.24 \\
\hline 05B0032 & 68 & 36.979 & 157 & 27.502 & 2010.6 & 982352.78 & 16.35 & -52.22 & 0.52 & 1.02 & -50.68 & 1.36 \\
\hline 05B0034 & 68 & 36.903 & 157 & 27.244 & 1961.4 & 982355.97 & 14.99 & -51.9 & 0.31 & 0.81 & -50.78 & 1.32 \\
\hline $05 \mathrm{~B} 0035$ & 68 & 36.899 & 157 & 27.229 & 1949.5 & 982356.47 & 14.37 & -52.12 & 0.38 & 0.89 & -50.85 & 1.25 \\
\hline $05 \mathrm{~B} 0036$ & 68 & 36.896 & 157 & 27.22 & 1940.9 & 982356.91 & 14.01 & -52.19 & 0.43 & 0.94 & -50.82 & 1.29 \\
\hline $05 \mathrm{~B} 0037$ & 68 & 36.891 & 157 & 27.21 & 1924.3 & 982357.84 & 13.38 & -52.25 & 0.49 & 1.02 & -50.74 & 1.36 \\
\hline 05B0038 & 68 & 36.888 & 157 & 27.201 & 1910.4 & 982358.63 & 12.86 & -52.29 & 0.47 & 1.01 & -50.81 & 1.3 \\
\hline 05B0039 & 68 & 36.883 & 157 & 27.189 & 1893.9 & 982359.51 & 12.2 & -52.39 & 0.43 & 1 & -50.96 & 1.16 \\
\hline 05B0040 & 68 & 36.878 & 157 & 27.178 & 1879.5 & 982360.33 & 11.67 & -52.44 & 0.36 & 0.95 & -51.13 & 0.99 \\
\hline 05B0041 & 68 & 36.874 & 157 & 27.164 & 1867.5 & 982360.92 & 11.14 & -52.56 & 0.39 & 1.01 & -51.16 & 0.97 \\
\hline $05 \mathrm{~B} 0042$ & 68 & 36.87 & 157 & 27.154 & 1860.6 & 982361.23 & 10.8 & -52.66 & 0.33 & 0.96 & -51.37 & 0.76 \\
\hline $05 \mathrm{~B} 0043$ & 68 & 36.866 & 157 & 27.141 & 1851.8 & 982361.66 & 10.4 & -52.76 & 0.32 & 0.97 & -51.47 & 0.66 \\
\hline $05 \mathrm{~B} 0044$ & 68 & 36.863 & 157 & 27.128 & 1844.3 & 982362.05 & 10.09 & $\begin{array}{l}-52.81 \\
\end{array}$ & 0.29 & 0.96 & -51.56 & 0.58 \\
\hline 05B0045 & 68 & 36.859 & 157 & 27.116 & 1838.4 & 982362.38 & 9.87 & -52.83 & 0.29 & 0.97 & -51.57 & 0.57 \\
\hline 05B0046 & 68 & 36.854 & 157 & 27.105 & 1832.5 & 982362.66 & 9.6 & -52.9 & 0.25 & 0.95 & -51.7 & 0.44 \\
\hline 05B0047 & 68 & 36.846 & 157 & 27.082 & 1827.2 & 982362.88 & 9.33 & -52.99 & 0.22 & 0.93 & -51.84 & 0.3 \\
\hline 05B0048 & 68 & 36.84 & 157 & 27.058 & 1823.5 & 982363.11 & 9.22 & -52.98 & 0.2 & 0.92 & -51.86 & 0.29 \\
\hline 05B0049 & 68 & 36.833 & 157 & 27.032 & 1819.9 & 982363.37 & 9.15 & -52.92 & 0.2 & 0.93 & -51.79 & 0.37 \\
\hline 05B0050 & 68 & 36.825 & 157 & 27.005 & 1815.5 & 982363.68 & 9.04 & -52.88 & 0.19 & 0.93 & -51.76 & 0.4 \\
\hline 05B0051 & 68 & 36.812 & 157 & 26.954 & 1808.9 & 982364.12 & 8.88 & -52.81 & 0.11 & 0.87 & -51.83 & 0.34 \\
\hline $05 \mathrm{~B} 0054$ & 68 & 37.115 & 157 & 26.871 & 1867.3 & 982361.61 & 11.55 & -52.14 & 0.25 & 0.82 & -51.07 & 0.89 \\
\hline $05 \mathrm{~B} 0055$ & 68 & 37.088 & 157 & 26.917 & 1890.9 & 982360.12 & 12.31 & -52.18 & 0.22 & 0.76 & -51.2 & 0.78 \\
\hline $05 \mathrm{~B} 0056$ & 68 & 37.066 & 157 & 26.958 & 1913.2 & 982358.74 & 13.05 & -52.2 & 0.2 & 0.72 & -51.28 & 0.71 \\
\hline $05 \mathrm{~B} 0057$ & 68 & 37.038 & 157 & 26.998 & 1957.5 & 982355.87 & 14.38 & -52.38 & 0.23 & 0.72 & -51.43 & 0.57 \\
\hline 05B0058 & 68 & 37.017 & 157 & 27.037 & 1975.1 & 982355.35 & 15.54 & -51.82 & 0.35 & 0.84 & -50.63 & 1.38 \\
\hline 05B0059 & 68 & 36.995 & 157 & 27.064 & 1973.9 & 982355.22 & 15.32 & -52.01 & 0.26 & 0.75 & -51 & 1.04 \\
\hline 05B0060 & 68 & 36.963 & 157 & 27.093 & 1942.8 & 982356.96 & 14.17 & -52.09 & 0.35 & 0.85 & -50.89 & 1.17 \\
\hline
\end{tabular}


Appendix. Principal facts of gravity data from Lakeview and Longview.-Continued

\begin{tabular}{|c|c|c|c|c|c|c|c|c|c|c|c|c|}
\hline $05 \mathrm{~B} 0061$ & 68 & 36.945 & 157 & 27.141 & 1909.9 & 982359.14 & 13.27 & -51.87 & 0.33 & 0.86 & -50.68 & 1.39 \\
\hline 05B0062 & 68 & 36.925 & 157 & 27.194 & 1925.9 & 982357.76 & 13.41 & -52.27 & 0.4 & 0.92 & -50.95 & 1.14 \\
\hline 05B0064 & 68 & 36.337 & 157 & 28.968 & 1885.6 & 982359.37 & 11.84 & -52.48 & 0.16 & 0.69 & -51.63 & 0.85 \\
\hline $05 \mathrm{~B} 0065$ & 68 & 36.353 & 157 & 28.903 & 1893.3 & 982359.09 & 12.27 & -52.3 & 0.17 & 0.69 & -51.44 & 1.03 \\
\hline 05B0066 & 68 & 36.367 & 157 & 28.835 & 1903.7 & 982358.65 & 12.79 & -52.14 & 0.18 & 0.7 & -51.26 & 1.2 \\
\hline 05B0067 & 68 & 36.38 & 157 & 28.752 & 1909.5 & 982358.6 & 13.27 & -51.85 & 0.11 & 0.62 & -51.12 & 1.33 \\
\hline 05B0068 & 68 & 36.396 & 157 & 28.708 & 1912.4 & 982358.08 & 13.01 & -52.22 & 0.19 & 0.7 & -51.33 & 1.11 \\
\hline 05B0069 & 68 & 36.411 & 157 & 28.656 & 1917.2 & 982357.81 & 13.18 & -52.21 & 0.2 & 0.71 & -51.3 & 1.13 \\
\hline 05B 0070 & 68 & 36.426 & 157 & 28.596 & 1930.2 & 982356.95 & 13.52 & -52.31 & 0.13 & 0.63 & -51.55 & 0.87 \\
\hline 05B0071 & 68 & 36.446 & 157 & 28.503 & 1989.7 & 982352.97 & 15.12 & -52.74 & 0.18 & 0.66 & -51.9 & 0.49 \\
\hline 05B0072 & 68 & 36.453 & 157 & 28.456 & 1973.5 & 982354.35 & 14.98 & -52.33 & 0.16 & 0.64 & -51.53 & 0.86 \\
\hline $05 \mathrm{~B} 0073$ & 68 & 36.463 & 157 & 28.392 & 1979.5 & 982354.84 & 16.02 & -51.49 & 0.16 & 0.64 & -50.69 & 1.69 \\
\hline 05B0074 & 68 & 36.475 & 157 & 28.334 & 1978.1 & 982355.32 & 16.35 & -51.12 & 0.17 & 0.65 & -50.3 & 2.07 \\
\hline $05 \mathrm{~B} 0075$ & 68 & 36.497 & 157 & 28.248 & 1973.4 & 982355.3 & 15.87 & -51.44 & 0.25 & 0.73 & -50.46 & 1.9 \\
\hline 05B0076 & 68 & 36.505 & 157 & 28.174 & 1940 & 982356.76 & 14.17 & -52 & 0.44 & 0.94 & -50.62 & 1.73 \\
\hline 05B0077 & 68 & 36.524 & 157 & 28.109 & 1955.8 & 982355.89 & 14.78 & -51.93 & 0.26 & 0.75 & -50.92 & 1.42 \\
\hline 05B0078 & 68 & 36.545 & 157 & 28.029 & 1948.1 & 982356.3 & 14.43 & -52.01 & 0.34 & 0.84 & -50.83 & 1.49 \\
\hline 05B0081 & 68 & 36.889 & 157 & 27.296 & 1961.9 & 982355.67 & 14.75 & -52.16 & 0.28 & 0.78 & -51.1 & 1.01 \\
\hline $05 \mathrm{~B} 0082$ & 68 & 36.866 & 157 & 27.331 & 1984.2 & 982354.28 & 15.48 & -52.19 & 0.33 & 0.83 & -51.03 & 1.09 \\
\hline $05 \mathrm{~B} 0083$ & 68 & 36.845 & 157 & 27.389 & 2000.4 & 982353.56 & 16.31 & -51.92 & 0.48 & 0.98 & -50.46 & 1.66 \\
\hline 05B0084 & 68 & 36.821 & 157 & 27.416 & 1982.9 & 982354.51 & 15.64 & -51.99 & 0.33 & 0.83 & -50.83 & 1.32 \\
\hline 05B0085 & 68 & 36.794 & 157 & 27.43 & 1968.1 & 982354.99 & 14.76 & -52.37 & 0.43 & 0.93 & -51.01 & 1.16 \\
\hline $05 \mathrm{~B} 0086$ & 68 & 36.768 & 157 & 27.448 & 1939.8 & 982356.72 & 13.84 & -52.32 & 0.45 & 0.97 & -50.9 & 1.29 \\
\hline $05 \mathrm{~B} 0087$ & 68 & 36.739 & 157 & 27.47 & 1914.8 & 982358.39 & 13.19 & -52.12 & 0.37 & 0.92 & -50.83 & 1.37 \\
\hline 05B0088 & 68 & 36.717 & 157 & 27.502 & 1898.6 & 982359.83 & 13.13 & -51.63 & 0.35 & 0.92 & -50.36 & 1.86 \\
\hline 05B0089 & 68 & 36.696 & 157 & 27.507 & 1877.9 & 982360.85 & 12.22 & -51.83 & 0.33 & 0.93 & -50.57 & 1.66 \\
\hline 05B0090 & 68 & 36.666 & 157 & 27.562 & 1867.6 & 982361.52 & 11.95 & -51.75 & 0.42 & 1.04 & -50.29 & 1.96 \\
\hline 05B0091 & 68 & 36.646 & 157 & 27.625 & 1870.8 & 982360.89 & 11.64 & -52.16 & 0.42 & 1.03 & -50.71 & 1.55 \\
\hline 05B0092 & 68 & 36.629 & 157 & 27.683 & 1874.3 & 982360.55 & 11.65 & -52.27 & 0.43 & 1.03 & -50.81 & 1.47 \\
\hline $05 \mathrm{~B} 0093$ & 68 & 36.61 & 157 & 27.745 & 1881.2 & 982360.12 & 11.89 & -52.27 & 0.43 & 1.01 & -50.83 & 1.46 \\
\hline 05B0094 & 68 & 36.59 & 157 & 27.808 & 1886.9 & 982359.66 & 11.99 & -52.36 & 0.42 & 0.99 & -50.95 & 1.35 \\
\hline $05 \mathrm{~B} 0095$ & 68 & 36.575 & 157 & 27.867 & 1894.3 & 982359.19 & 12.23 & -52.38 & 0.43 & 0.99 & -50.96 & 1.35 \\
\hline 05B0096 & 68 & 36.557 & 157 & 27.947 & 1917.2 & 982357.94 & 13.15 & -52.24 & 0.3 & 0.83 & -51.11 & 1.22 \\
\hline 05B0098 & 68 & 36.467 & 157 & 28.399 & 1976.9 & 982355 & 15.93 & -51.5 & 0.13 & 0.61 & -50.76 & 1.62 \\
\hline 05B0099 & 68 & 36.473 & 157 & 28.407 & 1975.8 & 982354.97 & 15.79 & -51.6 & 0.13 & 0.61 & -50.86 & 1.51 \\
\hline $05 \mathrm{~B} 0100$ & 68 & 36.479 & 157 & 28.415 & 1975.5 & 982354.89 & 15.67 & -51.7 & 0.22 & 0.7 & -50.78 & 1.59 \\
\hline 05B0101 & 68 & 36.485 & 157 & 28.424 & 1975.7 & 982354.83 & 15.62 & -51.76 & 0.24 & 0.72 & -50.8 & 1.56 \\
\hline $05 \mathrm{~B} 0102$ & 68 & 36.49 & 157 & 28.434 & 1975.9 & 982354.7 & 15.51 & -51.88 & 0.25 & 0.73 & -50.9 & 1.46 \\
\hline 05B0103 & 68 & 36.497 & 157 & 28.445 & 1976.6 & 982354.4 & 15.27 & -52.15 & 0.26 & 0.74 & -51.15 & 1.22 \\
\hline
\end{tabular}


Appendix. Principal facts of gravity data from Lakeview and Longview.-Continued

\begin{tabular}{|c|c|c|c|c|c|c|c|c|c|c|c|c|}
\hline 05B0104 & 68 & 36.506 & 157 & 28.453 & 1978.9 & 982353.96 & 15.03 & -52.46 & 0.27 & 0.75 & -51.44 & 0.92 \\
\hline $05 \mathrm{~B} 0105$ & 68 & 36.515 & 157 & 28.458 & 1981.9 & 982353.62 & 14.96 & -52.63 & 0.3 & 0.78 & -51.55 & 0.8 \\
\hline 05B0106 & 68 & 36.529 & 157 & 28.474 & 1988.1 & 982353.23 & 15.15 & -52.66 & 0.31 & 0.79 & -51.56 & 0.79 \\
\hline 05B0107 & 68 & 36.541 & 157 & 28.489 & 1992.4 & 982353.05 & 15.36 & -52.59 & 0.32 & 0.8 & -51.47 & 0.87 \\
\hline 05B0112 & 68 & 37.02 & 157 & 27.047 & 1985.5 & 982354.57 & 15.74 & -51.98 & 0.44 & 0.93 & -50.61 & 1.39 \\
\hline $05 \mathrm{~B} 0113$ & 68 & 37.023 & 157 & 27.062 & 1971 & 982355.38 & 15.18 & -52.04 & 0.33 & 0.82 & -50.89 & 1.13 \\
\hline 05B0114 & 68 & 37.025 & 157 & 27.075 & 1964.4 & 982355.78 & 14.95 & -52.05 & 0.43 & 0.92 & -50.7 & 1.31 \\
\hline $05 \mathrm{~B} 0115$ & 68 & 37.028 & 157 & 27.089 & 1956.8 & 982356.17 & 14.63 & -52.11 & 0.45 & 0.94 & -50.72 & 1.29 \\
\hline 05B0116 & 68 & 37.031 & 157 & 27.105 & 1955 & 982356.32 & 14.61 & -52.07 & 0.46 & 0.95 & -50.66 & 1.34 \\
\hline $05 \mathrm{~B} 0117$ & 68 & 37.033 & 157 & 27.12 & 1954.5 & 982356.41 & 14.65 & -52.01 & 0.41 & 0.9 & -50.7 & 1.31 \\
\hline 05B0118 & 68 & 37.035 & 157 & 27.136 & 1954.9 & 982356.35 & 14.62 & -52.06 & 0.53 & 1.02 & -50.51 & 1.49 \\
\hline 05B0119 & 68 & 37.038 & 157 & 27.152 & 1955.8 & 982356.25 & 14.6 & -52.1 & 0.57 & 1.06 & -50.47 & 1.53 \\
\hline 05B0120 & 68 & 37.039 & 157 & 27.168 & 1957.7 & 982356.22 & 14.75 & -52.02 & 0.52 & 1.01 & -50.49 & 1.51 \\
\hline 05B0121 & 68 & 37.042 & 157 & 27.184 & 1959.4 & 982356.12 & 14.81 & -52.02 & 0.57 & 1.06 & -50.39 & 1.61 \\
\hline $05 \mathrm{~B} 0122$ & 68 & 37.047 & 157 & 27.211 & 1962.7 & 982355.94 & 14.93 & -52.01 & 0.62 & 1.11 & -50.28 & 1.71 \\
\hline $05 \mathrm{~B} 0123$ & 68 & 37.053 & 157 & 27.24 & 1970.6 & 982355.48 & 15.22 & -51.99 & 0.69 & 1.18 & -50.12 & 1.87 \\
\hline $05 \mathrm{~B} 0125$ & 68 & 37.016 & 157 & 27.02 & 1967.2 & 982355.38 & 14.83 & -52.27 & 0.49 & 0.98 & -50.8 & 1.21 \\
\hline $05 \mathrm{~B} 0126$ & 68 & 37.014 & 157 & 27.006 & 1950.6 & 982356.21 & 14.1 & -52.42 & 0.6 & 1.1 & -50.72 & 1.31 \\
\hline 05B 0127 & 68 & 37.012 & 157 & 26.988 & 1925.9 & 982357.6 & 13.17 & -52.52 & 0.66 & 1.17 & -50.69 & 1.34 \\
\hline 05B 0128 & 68 & 37.01 & 157 & 26.974 & 1908.9 & 982358.56 & 12.53 & -52.58 & 0.66 & 1.19 & -50.73 & 1.31 \\
\hline 05B0129 & 68 & 37.007 & 157 & 26.961 & 1890.9 & 982359.58 & 11.86 & -52.64 & 0.62 & 1.17 & -50.85 & 1.19 \\
\hline 05B 0130 & 68 & 37.003 & 157 & 26.947 & 1872.8 & 982360.62 & 11.2 & -52.67 & 0.53 & 1.11 & -51.03 & 1.02 \\
\hline 05B 0131 & 68 & 37.001 & 157 & 26.93 & 1855.5 & 982361.67 & 10.62 & -52.66 & 0.44 & 1.05 & -51.17 & 0.88 \\
\hline $05 \mathrm{~B} 0132$ & 68 & 36.998 & 157 & 26.915 & 1844.5 & 982362.23 & 10.15 & -52.76 & 0.38 & 1.02 & -51.36 & 0.69 \\
\hline $05 \mathrm{~B} 0133$ & 68 & 36.995 & 157 & 26.901 & 1840.2 & 982362.45 & 9.96 & $\begin{array}{l}-52.8 \\
\end{array}$ & 0.36 & 1.01 & -51.43 & 0.62 \\
\hline 05B0134 & 68 & 36.991 & 157 & 26.883 & 1829.3 & 982363.1 & 9.6 & -52.79 & 0.33 & 1.01 & -51.45 & 0.61 \\
\hline 05B0135 & 68 & 36.989 & 157 & 26.868 & 1821.9 & 982363.52 & 9.32 & -52.82 & 0.3 & 1 & -51.52 & 0.54 \\
\hline 05B 0136 & 68 & 36.985 & 157 & 26.848 & 1814 & 982363.97 & 9.03 & -52.84 & 0.27 & 0.99 & -51.58 & 0.48 \\
\hline 05B0137 & 68 & 36.982 & 157 & 26.833 & 1810.2 & 982364.25 & 8.96 & -52.78 & 0.25 & 0.98 & -51.55 & 0.52 \\
\hline 05B 0138 & 68 & 36.978 & 157 & 26.817 & 1807.4 & 982364.41 & 8.86 & -52.79 & 0.25 & 0.99 & -51.55 & 0.52 \\
\hline 05B0139 & 68 & 36.975 & 157 & 26.803 & 1804.6 & 982364.57 & 8.75 & -52.79 & 0.25 & 0.99 & -51.55 & 0.52 \\
\hline 05B0140 & 68 & 36.97 & 157 & 26.776 & 1799 & 982364.99 & 8.66 & -52.7 & 0.25 & 1.01 & -51.44 & 0.63 \\
\hline 05B 0141 & 68 & 36.964 & 157 & 26.745 & 1793.8 & 982365.32 & 8.51 & -52.67 & 0.26 & 1.04 & -51.37 & 0.71 \\
\hline $05 \mathrm{~B} 0142$ & 68 & 37.138 & 157 & 26.829 & 1845.8 & 982362.84 & 10.74 & -52.22 & 0.21 & 0.82 & -51.19 & 0.76 \\
\hline $05 \mathrm{~B} 0143$ & 68 & 37.162 & 157 & 26.786 & 1836.8 & 982363.38 & 10.41 & -52.24 & 0.21 & 0.83 & -51.2 & 0.74 \\
\hline $05 \mathrm{~B} 0144$ & 68 & 37.181 & 157 & 26.749 & 1831.9 & 982363.7 & 10.25 & -52.23 & 0.25 & 0.88 & -51.1 & 0.83 \\
\hline $05 \mathrm{~B} 0146$ & 68 & 37.226 & 157 & 26.66 & 1823.1 & 982364.13 & 9.8 & -52.38 & 0.21 & 0.84 & -51.33 & 0.57 \\
\hline $05 \mathrm{~B} 0147$ & 68 & 37.247 & 157 & 26.615 & 1814.9 & 982364.69 & 9.57 & -52.33 & 0.21 & 0.86 & -51.26 & 0.63 \\
\hline 05B 0151 & 68 & 36.847 & 157 & 27.402 & 1985.2 & 982354.37 & 15.69 & -52.02 & 0.41 & 0.91 & -50.7 & 1.43 \\
\hline
\end{tabular}


Appendix. Principal facts of gravity data from Lakeview and Longview.-Continued

\begin{tabular}{|c|c|c|c|c|c|c|c|c|c|c|c|c|}
\hline $05 \mathrm{~B} 0152$ & 68 & 36.851 & 157 & 27.416 & 1969.8 & 982355.19 & 15.06 & -52.13 & 0.38 & 0.88 & -50.87 & 1.27 \\
\hline $05 \mathrm{~B} 0153$ & 68 & 36.855 & 157 & 27.431 & 1959.1 & 982355.85 & 14.7 & -52.12 & 0.36 & 0.87 & -50.89 & 1.24 \\
\hline 05B0154 & 68 & 36.858 & 157 & 27.446 & 1959.2 & 982355.73 & 14.59 & -52.23 & 0.42 & 0.93 & -50.88 & 1.25 \\
\hline $05 \mathrm{~B} 0155$ & 68 & 36.862 & 157 & 27.459 & 1961.3 & 982355.45 & 14.51 & -52.39 & 0.41 & 0.92 & -51.06 & 1.08 \\
\hline 05B0156 & 68 & 36.866 & 157 & 27.472 & 1962.4 & 982355.31 & 14.46 & -52.47 & 0.42 & 0.93 & -51.12 & 1.01 \\
\hline 05B0157 & 68 & 36.869 & 157 & 27.485 & 1964.2 & 982355.2 & 14.52 & -52.47 & 0.43 & 0.94 & -51.1 & 1.03 \\
\hline 05B 0158 & 68 & 36.872 & 157 & 27.498 & 1964.7 & 982355.17 & 14.53 & -52.47 & 0.44 & 0.95 & -51.08 & 1.05 \\
\hline 05B0159 & 68 & 36.875 & 157 & 27.513 & 1966 & 982355.14 & 14.62 & -52.44 & 0.45 & 0.95 & -51.04 & 1.09 \\
\hline $05 \mathrm{~B} 0160$ & 68 & 36.877 & 157 & 27.523 & 1967.4 & 982355.12 & 14.73 & -52.37 & 0.47 & 0.97 & -50.93 & 1.2 \\
\hline $05 \mathrm{~B} 0161$ & 68 & 36.881 & 157 & 27.537 & 1969.4 & 982355.02 & 14.82 & -52.35 & 0.49 & 0.99 & -50.87 & 1.26 \\
\hline 05B0162 & 68 & 36.884 & 157 & 27.55 & 1971.8 & 982354.9 & 14.92 & -52.33 & 0.5 & 1 & -50.83 & 1.3 \\
\hline 05B 0163 & 68 & 36.89 & 157 & 27.576 & 1977.3 & 982354.63 & 15.16 & -52.28 & 0.52 & 1.02 & -50.74 & 1.37 \\
\hline 05B0164 & 68 & 36.896 & 157 & 27.604 & 1981.2 & 982354.48 & 15.37 & -52.2 & 0.58 & 1.07 & -50.55 & 1.56 \\
\hline $05 \mathrm{~B} 0166$ & 68 & 36.84 & 157 & 27.374 & 1989.7 & 982354.09 & 15.84 & -52.02 & 0.39 & 0.89 & -50.74 & 1.39 \\
\hline 05B0167 & 68 & 36.837 & 157 & 27.366 & 1987.9 & 982353.86 & 15.44 & -52.36 & 0.47 & 0.97 & -50.92 & 1.22 \\
\hline 05B0168 & 68 & 36.833 & 157 & 27.354 & 1972.6 & 982354.61 & 14.76 & -52.52 & 0.57 & 1.07 & -50.88 & 1.26 \\
\hline 05B0169 & 68 & 36.829 & 157 & 27.338 & 1950.3 & 982355.82 & 13.87 & -52.65 & 0.63 & 1.14 & -50.88 & 1.27 \\
\hline $05 \mathrm{~B} 0170$ & 68 & 36.825 & 157 & 27.32 & 1927.7 & 982357.13 & 13.05 & -52.69 & 0.66 & 1.19 & -50.84 & 1.31 \\
\hline 05B0171 & 68 & 36.82 & 157 & 27.303 & 1902.4 & 982358.61 & 12.16 & -52.72 & 0.62 & 1.18 & -50.92 & 1.24 \\
\hline $05 \mathrm{~B} 0172$ & 68 & 36.816 & 157 & 27.286 & 1880.6 & 982359.9 & 11.4 & -52.74 & 0.51 & 1.11 & -51.12 & 1.04 \\
\hline $05 \mathrm{~B} 0173$ & 68 & 36.812 & 157 & 27.273 & 1870.7 & 982360.37 & 10.95 & -52.85 & 0.37 & 0.98 & -51.5 & 0.67 \\
\hline $05 \mathrm{~B} 0174$ & 68 & 36.809 & 157 & 27.26 & 1863.3 & 982360.62 & 10.5 & -53.05 & 0.4 & 1.03 & -51.62 & 0.55 \\
\hline 05B0175 & 68 & 36.805 & 157 & 27.248 & 1856.4 & 982360.88 & 10.11 & -53.2 & 0.36 & 1.01 & -51.83 & 0.34 \\
\hline 05B0176 & 68 & 36.802 & 157 & 27.235 & 1850.8 & 982361.14 & 9.86 & -53.27 & 0.34 & 1 & -51.93 & 0.24 \\
\hline $05 \mathrm{~B} 0177$ & 68 & 36.798 & 157 & 27.224 & 1843.8 & 982361.53 & 9.59 & -53.3 & 0.32 & 0.99 & -51.99 & 0.19 \\
\hline $05 \mathrm{~B} 0178$ & 68 & 36.794 & 157 & 27.209 & 1835.5 & 982362.05 & 9.34 & -53.26 & 0.31 & 1 & -51.95 & 0.23 \\
\hline 05B0179 & 68 & 36.79 & 157 & 27.192 & 1828 & 982362.53 & 9.11 & -53.23 & 0.28 & 0.99 & -51.96 & 0.22 \\
\hline $05 \mathrm{~B} 0180$ & 68 & 36.783 & 157 & 27.165 & 1821.3 & 982363.03 & 8.99 & -53.13 & 0.26 & 0.99 & $\begin{array}{l}-51.88 \\
\end{array}$ & 0.31 \\
\hline 05B0181 & 68 & 36.776 & 157 & 27.139 & 1817.2 & 982363.37 & 8.95 & -53.03 & 0.24 & 0.98 & -51.81 & 0.38 \\
\hline 05B0182 & 68 & 36.769 & 157 & 27.112 & 1811.1 & 982363.89 & 8.9 & -52.87 & 0.24 & 1 & -51.63 & 0.56 \\
\hline 05B0186 & 68 & 36.557 & 157 & 28.507 & 1999.7 & 982352.68 & 15.66 & -52.55 & 0.25 & 0.74 & -51.56 & 0.77 \\
\hline $05 \mathrm{~B} 0187$ & 68 & 36.569 & 157 & 28.527 & 2004.5 & 982352.33 & 15.75 & -52.62 & 0.37 & 0.86 & -51.39 & 0.93 \\
\hline $05 \mathrm{~B} 0188$ & 68 & 36.457 & 157 & 28.383 & 1970.7 & 982355.19 & 15.54 & -51.67 & 0.19 & 0.67 & -50.81 & 1.57 \\
\hline 05B0189 & 68 & 36.452 & 157 & 28.377 & 1962.5 & 982355.19 & 14.78 & -52.15 & 0.21 & 0.69 & -51.25 & 1.15 \\
\hline 05B0190 & 68 & 36.449 & 157 & 28.372 & 1959.8 & 982355.13 & 14.47 & $\begin{array}{l}-52.38 \\
\end{array}$ & 0.26 & 0.74 & -51.38 & 1.02 \\
\hline 05B0191 & 68 & 36.443 & 157 & 28.366 & 1944.5 & 982355.88 & 13.79 & -52.53 & 0.29 & 0.78 & -51.46 & 0.94 \\
\hline 05B0192 & 68 & 36.436 & 157 & 28.359 & 1929.8 & 982356.64 & 13.16 & -52.66 & 0.32 & 0.82 & -51.52 & 0.89 \\
\hline $05 \mathrm{~B} 0193$ & 68 & 36.43 & 157 & 28.352 & 1911.9 & 982357.67 & 12.52 & -52.69 & 0.31 & 0.83 & -51.55 & 0.87 \\
\hline 05B0194 & 68 & 36.424 & 157 & 28.344 & 1898.2 & 982358.47 & 12.04 & -52.7 & 0.24 & 0.77 & -51.69 & 0.73 \\
\hline
\end{tabular}


Appendix. Principal facts of gravity data from Lakeview and Longview.-Continued

\begin{tabular}{|c|c|c|c|c|c|c|c|c|c|c|c|c|}
\hline $05 \mathrm{~B} 0195$ & 68 & 36.418 & 157 & 28.337 & 1890 & 982358.91 & 11.71 & -52.75 & 0.21 & 0.76 & -51.78 & 0.64 \\
\hline 05B0196 & 68 & 36.413 & 157 & 28.331 & 1879.5 & 982359.53 & 11.35 & -52.75 & 0.19 & 0.75 & -51.81 & 0.62 \\
\hline 05B0197 & 68 & 36.408 & 157 & 28.323 & 1872.8 & 982359.77 & 10.96 & -52.92 & 0.24 & 0.82 & -51.86 & 0.57 \\
\hline 05B0198 & 68 & 36.402 & 157 & 28.314 & 1866.8 & 982360.07 & 10.7 & -52.97 & 0.21 & 0.8 & -51.96 & 0.48 \\
\hline 05B0199 & 68 & 36.396 & 157 & 28.308 & 1861.1 & 982360.38 & 10.48 & -53 & 0.2 & 0.8 & -52 & 0.44 \\
\hline $05 \mathrm{~B} 0200$ & 68 & 36.391 & 157 & 28.301 & 1854.9 & 982360.8 & 10.33 & -52.94 & 0.19 & 0.8 & -51.95 & 0.5 \\
\hline 05B0201 & 68 & 36.385 & 157 & 28.293 & 1849.6 & 982361.16 & 10.19 & -52.9 & 0.18 & 0.81 & -51.91 & 0.54 \\
\hline 05B0202 & 68 & 36.38 & 157 & 28.286 & 1845.3 & 982361.4 & 10.03 & -52.9 & 0.16 & 0.8 & -51.94 & 0.51 \\
\hline $05 \mathrm{~B} 0203$ & 68 & 36.368 & 157 & 28.273 & 1840.6 & 982361.69 & 9.89 & -52.89 & 0.15 & 0.8 & -51.94 & 0.52 \\
\hline 05B0204 & 68 & 36.357 & 157 & 28.26 & 1839.6 & 982361.69 & 9.81 & -52.94 & 0.14 & 0.79 & -52.01 & 0.47 \\
\hline $05 \mathrm{~B} 0205$ & 68 & 36.345 & 157 & 28.24 & 1839.1 & 982361.72 & 9.8 & -52.93 & 0.14 & 0.79 & -52 & 0.48 \\
\hline 05B0209 & 68 & 36.388 & 157 & 28.76 & 1920 & 982358.03 & 13.68 & $\begin{array}{l}-51.8 \\
\end{array}$ & 0.13 & 0.63 & -51.04 & 1.39 \\
\hline $05 \mathrm{~B} 0210$ & 68 & 36.393 & 157 & 28.765 & 1915.9 & 982358.13 & 13.4 & -51.95 & 0.11 & 0.62 & -51.22 & 1.22 \\
\hline 05B0211 & 68 & 36.398 & 157 & 28.768 & 1914.4 & 982357.93 & 13.04 & -52.25 & 0.2 & 0.71 & -51.34 & 1.1 \\
\hline $05 \mathrm{~B} 0212$ & 68 & 36.404 & 157 & 28.773 & 1914.6 & 982357.84 & 12.97 & -52.33 & 0.21 & 0.72 & -51.4 & 1.04 \\
\hline $05 \mathrm{~B} 0213$ & 68 & 36.41 & 157 & 28.78 & 1915.4 & 982357.72 & 12.92 & -52.41 & 0.22 & 0.73 & -51.46 & 0.97 \\
\hline 05B0214 & 68 & 36.416 & 157 & 28.784 & 1916.5 & 982357.63 & 12.92 & -52.44 & 0.23 & 0.74 & -51.47 & 0.96 \\
\hline $05 \mathrm{~B} 0215$ & 68 & 36.421 & 157 & 28.789 & 1917.1 & 982357.62 & 12.97 & -52.42 & 0.23 & 0.73 & -51.46 & 0.97 \\
\hline $05 \mathrm{~B} 0216$ & 68 & 36.427 & 157 & 28.795 & 1918.4 & 982357.56 & 13.02 & -52.41 & 0.24 & 0.74 & -51.43 & 0.99 \\
\hline 05B0217 & 68 & 36.433 & 157 & 28.801 & 1920.6 & 982357.47 & 13.14 & -52.37 & 0.25 & 0.75 & -51.37 & 1.05 \\
\hline 05B0218 & 68 & 36.439 & 157 & 28.806 & 1922.5 & 982357.38 & 13.22 & -52.35 & 0.27 & 0.77 & -51.31 & 1.1 \\
\hline $05 \mathrm{~B} 0219$ & 68 & 36.445 & 157 & 28.812 & 1924.5 & 982357.33 & 13.34 & -52.29 & 0.23 & 0.73 & -51.33 & 1.08 \\
\hline 05B 0220 & 68 & 36.457 & 157 & 28.821 & 1929.3 & 982357.02 & 13.48 & -52.33 & 0.29 & 0.78 & -51.26 & 1.14 \\
\hline 05B0221 & 68 & 36.468 & 157 & 28.834 & 1932.4 & 982356.88 & 13.62 & -52.29 & 0.29 & 0.78 & -51.22 & 1.18 \\
\hline $05 \mathrm{~B} 0222$ & 68 & 36.48 & 157 & 28.846 & 1939.2 & 982356.45 & 13.82 & -52.32 & 0.3 & 0.79 & -51.23 & 1.16 \\
\hline $05 \mathrm{~B} 0223$ & 68 & 36.491 & 157 & 28.858 & 1944.3 & 982356.2 & 14.04 & -52.28 & 0.3 & 0.79 & -51.19 & 1.2 \\
\hline 05B0225 & 68 & 36.375 & 157 & 28.746 & 1904.7 & 982358.69 & 12.91 & -52.05 & 0.11 & 0.63 & -51.31 & 1.14 \\
\hline 05B0226 & 68 & 36.37 & 157 & 28.741 & 1901.3 & 982358.67 & 12.58 & -52.26 & 0.2 & 0.72 & -51.34 & 1.12 \\
\hline $05 \mathrm{~B} 0227$ & 68 & 36.365 & 157 & 28.735 & 1896.4 & 982358.91 & 12.36 & -52.32 & 0.19 & 0.72 & -51.41 & 1.05 \\
\hline 05B 0228 & 68 & 36.358 & 157 & 28.728 & 1892.5 & 982359.18 & 12.27 & -52.27 & 0.18 & 0.71 & -51.38 & 1.08 \\
\hline 05B 0229 & 68 & 36.353 & 157 & 28.722 & 1889.3 & 982359.29 & 12.09 & -52.34 & 0.17 & 0.7 & -51.47 & 1 \\
\hline $05 \mathrm{~B} 0230$ & 68 & 36.346 & 157 & 28.715 & 1886 & 982359.58 & 12.07 & -52.25 & 0.16 & 0.7 & -51.39 & 1.08 \\
\hline 05B 0231 & 68 & 36.341 & 157 & 28.709 & 1883.5 & 982359.74 & 12.01 & -52.23 & 0.16 & 0.7 & -51.37 & 1.1 \\
\hline $05 \mathrm{~B} 0232$ & 68 & 36.335 & 157 & 28.702 & 1880.1 & 982359.93 & 11.88 & -52.25 & 0.16 & 0.71 & -51.38 & 1.09 \\
\hline 05B 0233 & 68 & 36.329 & 157 & 28.697 & 1877.1 & 982360.01 & 11.69 & -52.34 & 0.16 & 0.71 & -51.47 & 1.01 \\
\hline 05B0234 & 68 & 36.323 & 157 & 28.691 & 1874 & 982360.07 & 11.46 & -52.45 & 0.15 & 0.71 & -51.59 & 0.9 \\
\hline 05B0235 & 68 & 36.317 & 157 & 28.685 & 1871.8 & 982360 & 11.19 & -52.65 & 0.15 & 0.71 & -51.79 & 0.7 \\
\hline 05B 0236 & 68 & 36.311 & 157 & 28.675 & 1867.7 & 982360.19 & 11 & -52.7 & 0.15 & 0.72 & -51.83 & 0.66 \\
\hline $05 \mathrm{~B} 0237$ & 68 & 36.305 & 157 & 28.668 & 1865 & 982360.28 & 10.84 & -52.77 & 0.15 & 0.72 & -51.9 & 0.59 \\
\hline
\end{tabular}


Appendix. Principal facts of gravity data from Lakeview and Longview.-Continued

\begin{tabular}{|c|c|c|c|c|c|c|c|c|c|c|c|c|}
\hline 05B 0238 & 68 & 36.299 & 157 & 28.661 & 1862.5 & 982360.37 & 10.7 & -52.82 & 0.14 & 0.72 & -51.96 & 0.54 \\
\hline 05B 0239 & 68 & 36.294 & 157 & 28.656 & 1860.3 & 982360.41 & 10.55 & -52.9 & 0.14 & 0.72 & -52.04 & 0.46 \\
\hline 05B0240 & 68 & 36.283 & 157 & 28.644 & 1857.3 & 982360.49 & 10.35 & -52.99 & 0.13 & 0.72 & -52.14 & 0.38 \\
\hline 05B 0241 & 68 & 36.273 & 157 & 28.632 & 1855.1 & 982360.68 & 10.35 & -52.92 & 0.13 & 0.72 & -52.07 & 0.46 \\
\hline 05B 0245 & 68 & 36.601 & 157 & 27.768 & 1882.8 & 982359.94 & 11.88 & -52.34 & 0.4 & 0.98 & -50.96 & 1.34 \\
\hline 05B0246 & 68 & 36.59 & 157 & 27.743 & 1873.7 & 982360.65 & 11.74 & -52.17 & 0.37 & 0.97 & -50.83 & 1.47 \\
\hline $05 \mathrm{~B} 0247$ & 68 & 36.581 & 157 & 27.72 & 1866.2 & 982360.91 & 11.3 & -52.35 & 0.35 & 0.96 & -51.04 & 1.27 \\
\hline 05B0248 & 68 & 36.57 & 157 & 27.694 & 1859.7 & 982361.35 & 11.14 & -52.29 & 0.31 & 0.93 & -51.05 & 1.27 \\
\hline 05B0249 & 68 & 36.56 & 157 & 27.672 & 1854.4 & 982361.62 & 10.92 & -52.32 & 0.28 & 0.92 & -51.12 & 1.21 \\
\hline 05B 0250 & 68 & 36.543 & 157 & 27.63 & 1845.1 & 982362.21 & 10.66 & -52.27 & 0.18 & 0.84 & -51.25 & 1.09 \\
\hline 05B 0251 & 68 & 36.53 & 157 & 27.6 & 1830.8 & 982363.04 & 10.15 & -52.29 & 0.24 & 0.94 & -51.11 & 1.23 \\
\hline 05B 0252 & 68 & 36.522 & 157 & 27.583 & 1827.4 & 982363.71 & 10.51 & -51.81 & 0.2 & 0.91 & -50.7 & 1.64 \\
\hline $05 \mathrm{~B} 0253$ & 68 & 36.55 & 157 & 27.647 & 1850.6 & 982361.85 & 10.81 & -52.31 & 0.18 & 0.82 & -51.31 & 1.02 \\
\hline $05 \mathrm{~B} 0254$ & 68 & 36.612 & 157 & 27.794 & 1892 & 982359.31 & 12.1 & -52.43 & 0.47 & 1.03 & -50.93 & 1.36 \\
\hline $05 \mathrm{~B} 0255$ & 68 & 36.622 & 157 & 27.814 & 1898 & 982358.91 & 12.25 & $\begin{array}{l}-52.48 \\
\end{array}$ & 0.55 & 1.1 & -50.83 & 1.45 \\
\hline $05 \mathrm{~B} 0256$ & 68 & 36.632 & 157 & 27.837 & 1903.2 & 982358.59 & 12.41 & -52.5 & 0.66 & 1.21 & -50.63 & 1.65 \\
\hline $05 \mathrm{~B} 0257$ & 68 & 36.643 & 157 & 27.859 & 1917.9 & 982357.63 & 12.83 & -52.59 & 0.72 & 1.25 & -50.62 & 1.65 \\
\hline 05B0261 & 68 & 37.187 & 157 & 26.78 & 1838.3 & 982363.34 & 10.48 & -52.22 & 0.29 & 0.9 & -51.03 & 0.9 \\
\hline $05 \mathrm{~B} 0262$ & 68 & 37.193 & 157 & 26.811 & 1845.6 & 982362.92 & 10.75 & -52.2 & 0.33 & 0.93 & -50.94 & 0.98 \\
\hline $05 \mathrm{~B} 0263$ & 68 & 37.199 & 157 & 26.846 & 1855 & 982362.35 & 11.05 & -52.22 & 0.36 & 0.94 & -50.92 & 1 \\
\hline 05B0264 & 68 & 37.205 & 157 & 26.88 & 1863.8 & 982361.86 & 11.38 & -52.19 & 0.4 & 0.96 & -50.83 & 1.08 \\
\hline $05 \mathrm{~B} 0265$ & 68 & 37.212 & 157 & 26.911 & 1872.9 & 982361.33 & 11.71 & -52.17 & 0.45 & 1 & -50.72 & 1.19 \\
\hline 05B0266 & 68 & 37.219 & 157 & 26.943 & 1884.4 & 982360.65 & 12.1 & -52.17 & 0.49 & 1.03 & -50.65 & 1.25 \\
\hline 05B0267 & 68 & 37.225 & 157 & 26.973 & 1895.6 & 982359.98 & 12.47 & -52.18 & 0.57 & 1.09 & -50.52 & 1.37 \\
\hline 05B0268 & 68 & 37.175 & 157 & 26.714 & 1825.4 & 982363.96 & 9.9 & -52.36 & 0.25 & 0.89 & -51.22 & 0.71 \\
\hline 05B0269 & 68 & 37.168 & 157 & 26.683 & 1818.3 & 982364.31 & 9.59 & -52.43 & 0.24 & 0.9 & -51.29 & 0.65 \\
\hline $05 \mathrm{~B} 0270$ & 68 & 37.162 & 157 & 26.652 & 1813.8 & 982364.42 & 9.29 & $\begin{array}{l}-52.58 \\
\end{array}$ & 0.24 & 0.91 & -51.43 & 0.51 \\
\hline $05 \mathrm{~B} 0271$ & 68 & 37.155 & 157 & 26.618 & 1806.2 & 982364.65 & 8.8 & -52.8 & 0.24 & 0.94 & -51.62 & 0.32 \\
\hline $05 \mathrm{~B} 0272$ & 68 & 37.149 & 157 & 26.587 & 1800.9 & 982364.81 & 8.47 & -52.95 & 0.24 & 0.96 & -51.75 & 0.2 \\
\hline $05 \mathrm{~B} 0273$ & 68 & 37.143 & 157 & 26.555 & 1798.3 & 982364.91 & 8.34 & -53 & 0.23 & 0.96 & -51.81 & 0.15 \\
\hline 05B 0274 & 68 & 37.137 & 157 & 26.521 & 1793.2 & 982365.27 & 8.22 & -52.94 & 0.23 & 0.97 & -51.74 & 0.22 \\
\hline $05 \mathrm{~B} 0275$ & 68 & 37.13 & 157 & 26.488 & 1788.9 & 982365.6 & 8.15 & -52.86 & 0.23 & 0.99 & -51.64 & 0.33 \\
\hline $05 \mathrm{~B} 0276$ & 68 & 37.123 & 157 & 26.456 & 1785 & 982365.87 & 8.07 & -52.81 & 0.22 & 1 & -51.59 & 0.39 \\
\hline 05B0277 & 68 & 37.116 & 157 & 26.423 & 1779.8 & 982366.19 & 7.9 & -52.81 & 0.24 & 1.04 & -51.53 & 0.45 \\
\hline LONGVIEW & 68 & 36.907 & 157 & 27.255 & 1967.7 & 982355.5 & 15.11 & -52 & 0.28 & 0.78 & -50.94 & 1.16 \\
\hline
\end{tabular}




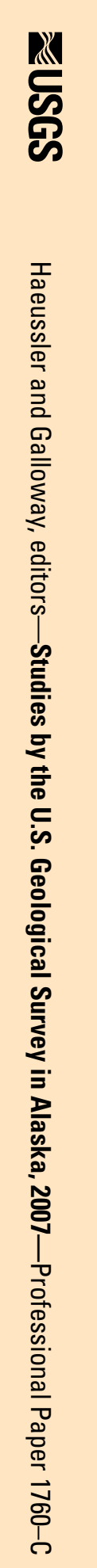

